NBER WORKING PAPER SERIES

\title{
ENTREPRENEURSHIP AND THE CITY
}

\author{
Edward L. Glaeser
}

Working Paper 13551

http://www.nber.org/papers/w13551

\author{
NATIONAL BUREAU OF ECONOMIC RESEARCH \\ 1050 Massachusetts Avenue \\ Cambridge, MA 02138 \\ October 2007
}

Kristina Tobio provided superb research assistance and oversaw a team consisting of Yün-ke Chin-Lee, Elizabeth Cook, Andrew Davis, and Charles Redlick. This paper has been written for a Kauffman Foundation conference on entrepreneurship and for a related conference volume. Jason Furman provided helpful comments. The views expressed herein are those of the author(s) and do not necessarily reflect the views of the National Bureau of Economic Research.

(C) 2007 by Edward L. Glaeser. All rights reserved. Short sections of text, not to exceed two paragraphs, may be quoted without explicit permission provided that full credit, including (C notice, is given to the source. 
Entrepreneurship and the City

Edward L. Glaeser

NBER Working Paper No. 13551

October 2007

JEL No. R0

\begin{abstract}
$\underline{\text { ABSTRACT }}$
Why do levels of entrepreneurship differ across America's cities? This paper presents basic facts on two measures of entrepreneurship: the self-employment rate and the number of small firms. Both of these measures are correlated with urban success, suggesting that more entrepreneurial cities are more successful. There is considerable variation in the self-employment rate across metropolitan areas, but about one-half of this heterogeneity can be explained by demographic and industrial variation. Self-employment is particularly associated with abundant, older citizens and with the presence of input suppliers. Conversely, small firm size and employment growth due to unaffiliated new establishments is associated most strongly with the presence of input suppliers and an appropriate labor force. I also find support for the Chinitz (1961) hypothesis that entrepreneurship is linked to a large number of small firms in supplying industries. Finally, there is a strong connection between area-level education and entrepreneurship.
\end{abstract}

Edward L. Glaeser

Department of Economics

315A Littauer Center

Harvard University

Cambridge, MA 02138

and NBER

eglaeser@harvard.edu 


\section{Introduction}

In 1961, Benjamin Chinitz described Pittsburgh and New York City as "contrasts in agglomeration." While New York City appeared to be full of independent entrepreneurs, Pittsburgh was dominated by a small number of large, vertically integrated firms. Thirty years later, Annalee Saxenian described a similar contrast between the highly entrepreneurial computer industry in Silicon Valley and its much more corporate counterpart in Boston's Route 128. Today, measures of entrepreneurship, like the self-employment rate, continue to show sizable differences across metropolitan areas. One in every ten workers in the West Palm Beach metropolitan area is self-employed; the comparable number for Dayton, Ohio, is less than one in thirty.

Why are some cities so much more entrepreneurial than others? This paper attempts to analyze some basic facts about entrepreneurship across urban areas. In Section II of this paper, I discuss two widely available measures of entrepreneurship: the self-employment rate and average firm size. Both of these measures are quite imperfect attempts to capture the number of entrepreneurs relative to the overall amount of employment in an industry. Though it has a long history of being used to study entrepreneurship, the self-employment rate is particularly oriented towards the smallest entrepreneurs and makes little distinction between Michael Bloomberg and a hot dog vendor outside of city hall (Evans and Jovanovic, 1989; Blanchflower and Oswald, 1998). Conversely, the number of workers per firm is more likely to capture the presence of larger scale entrepreneurs. One problem with either measure is that when entrepreneurs are successful, they will hire more workers, and this will cause the self-employment rate in the industry to fall and the number of firms per worker to decline. The problems with both measures push towards using more dynamic measures, such as new establishment creation, but these measures require the use of restricted datasets such as the Longitudinal Research Database (LRD), which I will discuss at the end of the paper. 
In Section II, I examine the patterns of entrepreneurial activity within individual industries as well. Generally, the correlations across metropolitan areas between self-employment rates across industry groups are fairly high, except for the self-employment rate in high-skilled manufacturing. For instance, West Palm Beach is among the five most entrepreneurial places in retail trade; wholesale trade and transportation; education, health and social services; low skilled manufacturing; and other services. The correlations of self-employment rates across income categories within a metropolitan area are also quite positive, although somewhat less strong. The self-employment rates are also related to the firm size-based measures of entrepreneurship.

Section II concludes by looking at the correlation between these entrepreneurship measures and city growth. Glaeser et al. (1992) and Miracky (1994) both found a connection between small firm size and employment growth. I duplicate this result, and find that an abundance of small firms is strongly correlated to later employment growth in a city industry. I also find that the self-employment rate at the city level in 1970 predicts growth in population and income over the next 30 years. While these finding are far from conclusive, they do suggest that local entrepreneurship helps explain why some cities grow faster than others.

Section III describes four theories that explain why entrepreneurship differs so much across space. The simplest theory holds that entrepreneurship reflects a supply of potential entrepreneurs with plenty of either general human capital or human capital that is particularly valuable for entrepreneurs. According to this view, cities differ in their human capital base for historical reasons, and these initial human capital differences drive the level of entrepreneurship today. A second theory emphasizes a local "culture of entrepreneurship". This theory predicts that exogenous variables that cause an increase in entrepreneurship in one sector of the economy will also increase the level of entrepreneurship in other sectors of the economy.

A third theory emphasizes the presence of inputs to entrepreneurship such as capital, labor and goods. A variant of this theory, following from Chinitz (1961), emphasizes the presence of 
small, independent input suppliers. A fourth theory emphasizes the presence of a large customer base.

In Section IV, I evaluate these four hypotheses using data on self-employment, firm size and employment growth due to unaffiliated plant formation. Self-employment is strongly connected to age, education and industry. These variables can explain roughly 50 percent of the variation in self-employment rates across metropolitan areas, and this fact supports the view that entrepreneurial people explain a fair amount of why some places are more entrepreneurial than others. Using firm size data, I also find that basic demographic variables can explain about onethird of the variation in firm sizes across metropolitan areas.

By contrast, the evidence for the "culture of entrepreneurship" hypothesis is much weaker. Looking across metropolitan areas, there is a tendency for people who live in metropolitan areas filled with more entrepreneurial industries to be more entrepreneurial, holding their industry constant. This is the only positive evidence for a culture of entrepreneurship, and it could be explained by many theories, such as the tendency of more entrepreneurial industries to locate in places with more entrepreneurial people. When I look at industry clusters within metropolitan areas, there is no correlation between entrepreneurial industries and individual entrepreneurship, again holding the individual industry constant. The firm size evidence also points against the culture of entrepreneurship theory.

Both the self-employment and firm size data show that the entrepreneurship levels are higher when industry employment is lower. One explanation for this phenomenon is that if the number of entrepreneurs is relatively constant over space, but the success of entrepreneurs differs, then we should expect to see more employment in areas where entrepreneurs are more successful, and that higher level of employment then causes the entrepreneurship rate to look lower.

The self-employment rate is correlated with the presence of input suppliers. It is not correlated with the presence of customers, appropriate labor supply, venture capitalists or small firms that 
supply inputs. The self-employment level in retail industries does rise in big cities, but this is the only demand-side effect that is readily apparent.

Average firm size tends to decrease with the availability of inputs, and the presence of many small input suppliers is also highly indicative of a large number of small firms, just as Chinitz suggests. Firm size is also weakly associated with demand, but the presence of the appropriate labor force seems to be the most important variable for explaining an abundance of small firms. The entrepreneurs seem to be in areas where there are lots of workers, either because they are attracted by those workers or because these workers provide the pool of potential entrepreneurs.

The regressions taken from Dumais, Ellison and Glaeser (1997) confirm the importance of labor supply. New plant growth is associated with input suppliers and customers, but the impact of workers is far more important. We also find that intellectual connections across industries are important.

Section V concludes and emphasizes that these results should be seen as a tentative first step in the task of explaining the variation in entrepreneurship across metropolitan areas. My limited evidence suggests that local entrepreneurship depends mainly on having the right kind of people. Older, skilled workers are more likely to be entrepreneurs, and entrepreneurship in an industry depends strongly on the presence of workers who both provide the pool of labor for entrepreneurs and are themselves the source of new entrepreneurship.

\section{The Measurement of Entrepreneurship}

In this section, I discuss the measurement of entrepreneurship across space. Perhaps the most natural individual measure of entrepreneurship is the self-employment rate, which captures the share of people who lead their own enterprise. Since self-employment rates are easy to measure, they have been the standard for much of the empirical work in this area (Evans and Jovanovic, 
1989; Blanchflower and Oswald, 1998). The downside of using self-employment rates is that the raw measure is extremely coarse. There are over 8.5 million self-employed Americans in the 2000 Census, and that group includes both many of the richest and many of the poorest people in the country. Since I am interested not only in the amount of entrepreneurial activity, but also in the amount of successful entrepreneurial activity, I will examine both the total amount of selfemployment and the amount of self-employment in different income categories.

Income categories offer one way of dividing up self-employment rates; industry grouping represents a second means of doing so. Since self-employment information comes from the Census, respondents are identified by their industry group using the North American Industrial Classification System (NAICS). This system offers finely detailed industry groupings, which I will use in later analysis in this paper. For the purposes of this preliminary data description, I divide the overall population into ten groups based on one and two-digit NAICS codes.

The essential division is along one-digit lines. Within the initial nine different one digit codes, I eliminate all of the workers in agriculture, since my focus is on urban areas, and in public administration and the military, since my focus is on the private sector. This leaves me with seven one-digit codes. I then divide each of the three largest one-digit codes - manufacturing (NAICS code 3), trade (NAICS code 4) and information-related services (NAICS code 5) - into two groups. Manufacturing and information-related services are divided on the basis of the average education level in the two-digit NAICS code, separating the self-employed in the more educated two-digit industry codes from the self-employed in the less educated two-digit codes. Since education is correlated with both technology and income, it provides a reasonable dividing line. I also divide the trade related industries into a retail trade category and a wholesale trade, transportation and warehousing category. This division is based on the fact that entrepreneurship in retail trade is likely to be correlated with ordinary consumers in a way that is less true for the other trade industries. 
Table 1 shows the distribution of the non-agricultural, non-governmental workforce across these ten groupings. The first column shows the overall share of employment in each one of the industry categories. The second column shows the share of the total overall self-employment in each of these industry categories, and the third column gives the self-employment rate within each industry category.

The first category of mining, utilities and construction has only 8 percent of total employment in the United States, but it accounts for more than 15 percent of the total self-employment in the United States. The self-employment rate in this category is the highest across all industry groupings at almost 10 percent, and this mainly reflects the high self-employment rates in construction. The home building business is populated by thousands of independent contractors, and is in many ways one of the most entrepreneurial sectors of the economy.

The next two rows in the table show the results for high and low skilled manufacturing. As there tend to be large economies of scale in these industries, self-employment rates are low. High skilled manufacturing is an area where less than one percent of its labor force is self-employed. This fact clearly illustrates the mismatch between the number of people who are self-employed and the importance of entrepreneurship within an industry. Certainly, some of the country's most important entrepreneurs are in high skilled manufacturing, but there are very few of them relative to the overall workforce in those industries. This fact is a warning against treating the self-employment rate as any kind of definitive measure of entrepreneurship.

Both retail trade and wholesale trade and transportation have self-employment rates of around five percent. The share of self-employed workers in the less skilled information services is similar. The self-employment rate in high skilled information services is over 8 percent. While the more skilled manufacturing industries have less self-employment, the more skilled information services have more self-employment. This reflects both the lower capital requirements and the general entrepreneurial nature of many information services such as accounting, management consulting and law. 
The self-employment rate in education, health and social services is quite low. Non-profit firms figure prominently in this sector and many of them are extremely large. The self-employment rate in entertainment, accommodation and food services is over 5 percent. Given the large number of independent food salesman, it makes sense that this number is rather high. The final grouping is "other services," which includes a hodgepodge of service industries ranging from "repair and maintenance services" to "personal and laundry services" to "religious services". The self-employment rate in this sector is almost 8 percent, and it is the third most entrepreneurial of these industry groupings.

Entrepreneurs differ in the industries they choose, and they also differ in the degree of their financial success. When I turn to the cross-metropolitan statistical area data, I will be interested in examining both the correlates of self-employment and the correlates of being prosperous and self-employed. Table 2 shows the distribution of prosperity among the self-employed across the ten industry groups.

The columns of the table represent five different financial groupings. The lowest group includes people earning less than 23,000 dollars, which are those people in the bottom quartile of the income distribution. The second group includes people earning between 23,000 and 53,000 dollars, which are those people in the middle two quartiles of the income distribution. The third group includes people earning between 53,000 and 110,000 dollars, which are those people in the top quartile of the income distribution, but outside of the top five percent of the income distribution. The fourth group earns between 110,000 and 175,000 dollars, which means that they earn more than 95 percent of the employed workers in the Census, but that they are not among the elite group of workers whose income has been top-coded. The fifth and final group includes only those whose incomes have been top-coded.

The industry groups are ranked by mean earnings, with high skilled information services at the top of the table and entertainment, accommodation and food services at the bottom. The average 
income for that top group is more than double the average income in the bottom group. The matrix gives two entries in every cell. The top entry refers to a ratio that is calculated as the number of people in that particular industry group and in that particular earnings category who are self-employed, divided by the total number of people in that particular industry group who are self-employed. The bottom entry refers the ratio that is calculated as the number of people in that particular industry group and particular earnings category who are self-employed, divided by the total number of people in that particular earnings category who are self-employed. The top numbers sum horizontally to equal one hundred percent; the bottom numbers sum vertically to equal one hundred percent. The top figures give a sense of the income distribution of the industry; the bottom numbers tell us what share of total self-employed people earning a certain amount work for a particular industry group.

For example, the top row tells that 14.74 percent of the self-employed in high skilled information services are in the bottom quartile of the income distribution while 12.61 percent of them are in the top coded category. 29.39 percent of all self-employed people in the top coded category are in high skilled information services. This industry group is the largest repository of highly paid entrepreneurs. The second largest repository is in education, health and social services, which has 26.88 percent of the top coded self-employed workers. There is much truth to the view that doctors and lawyers provide a large share of the most successful self-employed people. Interestingly, the education, health and social service group is particular unequal, and overall has a relatively low average income grouping. Together, the high skilled information services and the education, health and social services industry groups contain approximately 56 percent of the top coded self-employed workers, and almost 50 percent of the self-employed people in the top five percent of the income distribution.

The poorest industry groups are entertainment, accommodation and food services and "other services", which includes industries such as "repair and maintenance services" and "personal and laundry services". More than 70 percent of the self-employed people in these areas are in the bottom three quarters of the income distribution. Of course, they are not particularly poorer than the U.S. population is as a whole, but they are not particularly richer as a group either. Retail 
trade and low skilled manufacturing are the other groups that have an income distribution that is closest to the overall U.S. income distribution. However, these people are still vastly overrepresented among the top-coded earners, which suggests that even in these industry groups there is some chance of doing quite well.

The earnings distributions for low skilled information services; wholesale trade and transportation; and mining, utilities and construction are all quite similar. Average earnings in these sectors are clustered around 45,000 dollars, and between 5 and 7 percent of their populations are in the top-coded category. High skilled manufacturing has average earnings that are higher than any of these groups, and more than 8 percent of its entrepreneurs have top-coded income levels.

One issue with comparing the earnings of self-employed workers with the U.S. population as a whole is that the earnings of the self-employed typically include both the returns to their labor and the returns to any capital that they have invested. The earnings of most workers do not include any returns to capital. As a result, the high incomes earned by some self-employed workers surely overstate their labor income.

I now turn to the heterogeneity of self-employment rates across metropolitan areas. To get a sense of the range of self-employment rates, Table 3 presents the five metropolitan areas with the highest and lowest self-employment rates overall and in each of the ten industry groups. The top panel of Table 3 shows that the heterogeneity in the overall self-employment rate is significant but not extreme. All but eight of the country's metropolitan areas have overall self-employment rates, across all industries, between 3.2 and 7.76 percent. This top panel shows some outliers, like West Palm Beach and Honolulu, and these MSAs reappear in Table 3 in some of the other panels representing our ten different industry groups. The problems with this overall measure are well illustrated by the fact that San Jose, CA, has among the lowest self-employment rates in the country. Despite all those Silicon Valley entrepreneurs who have changed the world, their region has, on a per capita basis, far fewer entrepreneurs than all but four other areas. 
The remaining panels give us the top and bottom five metropolitan areas ranked by the selfemployment rate within each MSA. The self-employment rate is defined as the share of workers in that industry group who are self-employed. In these areas, the heterogeneity can be striking. The self-employment rate in mining, utilities and construction is more than 20 percent in Fort Wayne, Indiana, but less than 2 percent in Modesto, California. In high skilled information services, the self-employment rate in Spokane, Washington, is 16 percent, while the selfemployment rate in Bakersfield, California is 3.13 percent.

In some cases, these differences are driven by industrial differences within the categories. Construction has a high self-employment rate, while mining and utilities do not. As such, MSAs that have a large portion of their labor force employed in mining will likely have low overall self-employment rates within the aggregated mining, utilities and construction industry group, because the very low self-employment rates in mining will offset any high self-employment rates in construction in those areas. Thus, it is clear that controlling for very finely detailed industry groups will be important for any further work on the local determinants of entrepreneurship.

Still, the continuing reappearance of some metropolitan areas in a wide range of different categories makes it clear that industrial differences cannot be entirely responsible for the variation across metropolitan areas. For example, West Palm Beach ranks in the top five for five of the ten industry groups (low skilled manufacturing; retail trade; high skilled information services; education; health and social services; and other services). Honolulu is in the top five for three different industry groups, and Springfield, Massachusetts, is in the bottom five for three different industry groups.

The heavy representation of Florida's cities in so many of the top five lists is quite striking. This might represent a preponderance of older citizens who have enough human capital to operate independently and who prefer the control that comes from working on their own. Alternatively, 
it might represent a response to the physical distance of Florida from the locations of many of the larger corporations in America.

Table 4 presents an overview of the degree to which self-employment rates across these industrial categories are correlated with the overall self-employment rate. The first column gives the correlation of the overall self-employment rate in an MSA with the self-employment rate within each industry group in an MSA, which is calculated as the number self-employed workers in the industry group divided by total employment in the industry group. The third column shows correlations of the same self-employment rates using a smaller sample of people earning over 75,000 dollars a year. The second column gives the correlation between the overall selfemployment rate in an MSA with the share of the metropolitan area's workers that are selfemployed in each of the industry groups, which is calculated by dividing the number of selfemployed workers in an industry group by the total number of self-employed workers in all industries in the MSA.

The correlations shown in the first column can be separated into three groups. Five of the industries have self-employment rates that have a correlation with the overall self-employment rate between 61 and 66 percent. These five are both information services groups; both types of trade; and mining, utilities and construction. The second column shows that the overall selfemployment rate is also quite correlated with the share overall city's workforce that is selfemployed in those industry groups. Figure 1 shows the correlation across MSAs between the overall self-employment rate and the share of the workforce that is self-employed in retail trade.

The second group includes four industries with self-employment rates that have a correlation with the overall self-employment rate ranging from 35 percent (low skilled manufacturing) to 50 percent (other services). The other two industry groups in this set are education, health and social services and entertainment, accommodation and food services. 
The final industry group is high skilled manufacturing, which has an insignificant and negative correlation with the overall self-employment rate. The correlation between the self-employment rate in this MSA-industry group and the overall self-employment rate this MSA is shown in Figure 2. While self-employment in most of the industry groups share some degree of connection with self-employment in the metropolitan area as a whole, self-employment in high skilled manufacturing is something unto itself and is unrelated to self-employment in any of the other industries.

My second measure of entrepreneurship for the metropolitan area is average firm size. When the same amount of employment is spread over more firms, there must be more firm leaders or entrepreneurs per worker. My firm size data is taken from County Business Patterns and it is also available for a wide range of industries. In principle, this measure would not need to be all that highly correlated with self-employment, especially if self-employed people work overwhelmingly on their own, because self-employed individuals are specifically excluded from County Business Patterns reporting.

The fourth column of Table 4 shows the correlation between average firm size within each industry group and the self-employment rate within that group. Overall, there is a robust -67.6 percent correlation between average firm size and the self-employment rate, which is shown in Figure 3. Figure 3 shows that West Palm Beach has among the lowest number of workers per firm. There is considerable heterogeneity across the industry groups. In the County Business Patterns data, I did not separate manufacturing or information services into high and low skilled categories. Therefore, the table reports the correlation with firm size in all manufacturing and all information services.

The correlations are generally quite significantly negative: larger average firm sizes are highly correlated with lower self-employment rates. The strongest correlation is in wholesale trade and transportation, and five of the correlations are stronger than -48 percent. The correlations for the two more consumer oriented industries - retail trade and entertainment, accommodation and 
food services - are close to -40 percent. The weakest correlation is in other services which is less than -20 percent. This correlation is shown in Figure 4.

In the later empirical work, I will use both measures of entrepreneurship. The primary advantage of the self-employment rate is that I am able to control for individual level characteristics. With the firm size data, I will only be able to control for aggregate statistics at the metropolitan area level and the industrial composition of the metropolitan area. Both measures are quite imperfect, but they are convenient and surely at least correlated with some aspects of local entrepreneurship.

\section{Entrepreneurship and City Growth}

I now turn to the correlation between the entrepreneurship measures and metropolitan growth. Glaeser et al. (1992) found a significant correlation between average firm size and employment growth at the city-industry level, and Miracky (1994) confirmed this result for a larger sample. Using data from 1977 and 2000 County Business Patterns, I can relate employment growth within each metropolitan area-industry cell to the logarithm of the average firm size in the metropolitan area. In this case, in part because of a desire to avoid suppressed data, I use the following, quite coarse, industry groupings: "manufacturing", "services," "finance, insurance and real estate", "retail trade", "wholesale trade", "construction," "mining" and "transportation, warehousing and utilities."

Using these measures, I estimate the regression:

(1) $\log \left(\frac{E m p_{2000}}{E m p_{1977}}\right)=-\underset{(.04)}{.60} \log \left(\frac{F i r m s_{1977}}{E m p_{1977}}\right)+\underset{(.01)}{.04} \log \left(E m p_{1977}\right)+M S A$ and Industry Dummies

Standard errors are in parentheses and clustered at the metropolitan area level. There are 2735 observations. A .1 log point increase in average firm size is associated with a .06 decrease in 
industry employment growth over the 1977-2000 period. This effect has a t-statistic of 15 and is quite statistically significant.

If these regressions are run independently for each of the seven broad industry groups (obviously without metropolitan area dummies), the effect of firm size is negative and significant in each one of the groups, and ranges from - .31 in retail trade to -.86 in wholesale trade.

If I estimate this relationship at the metropolitan area level, I find

(2) $\log \left(\frac{E m p_{2000}}{E m p_{1977}}\right)=-\underset{(.10)}{.88} \log \left(\frac{F i r m s_{1977}}{E m p_{1977}}\right)+\underset{.02)}{.02} \log \left(E m p_{1977}\right)$

There are 353 observations in this regression. Again the result is statistically significant and even larger economically. Figure 5 shows the univariate relationship between employment growth and average firm size at the metropolitan area level.

The firm size effect is quite robust, but it is less clear what this effect means. It could indeed be measuring entrepreneurship, but it could also measure competition (as suggested by Glaeser et al., 1992) or perhaps even the timing in the firm cycle (as suggested by Miracky, 1994). I now turn to the other measure of entrepreneurship: the self-employment rate.

At the metropolitan area level, self-employment does predict metropolitan area growth. In this case, I estimate:

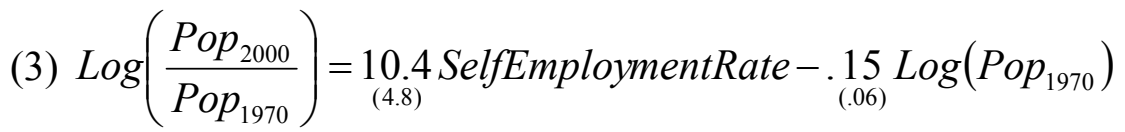

However, the self-employment rate does not predict growth within industries. Still, the results of firm size and self-employment at the metropolitan area level help to motivate the analysis of the causes of heterogeneity in these variables across space. 


\section{Why Does Entrepreneurship Differ Across Cities?}

In this section, I discuss the four different theories that can explain the heterogeneity of entrepreneurship. I will test these four theories empirically in the next section.

Hypothesis \# 1: Supply of Entrepreneurs

Perhaps the simplest hypothesis about the heterogeneity of entrepreneurship across space is that some people are inherently more entrepreneurial than others because of their education levels, ages or industry of choice. Better educated people could easily have more skills to succeed as entrepreneurs. Older people might have accumulated more capital or experience that might make entrepreneurship more attractive. Finally, some industries inherently have lower capital requirements, and this might make entrepreneurship easier.

This hypothesis suggests that controlling for individual characteristics and the industry mix of a metropolitan area will explain a significant amount of the variation in entrepreneurship rates across metropolitan areas. Perhaps the most intuitive means of testing this hypothesis is to look at raw entrepreneurship rates at the metropolitan area level, and then to compare those rates with rates that are calculated as the residuals from individual level regressions that control for individual characteristics and industries. If this hypothesis is correct, the variance of metropolitan area self-employment rates should decline substantially by controlling for the industry mix in the metropolitan area. I can also test this hypothesis by looking at the extent to which area-level demographic variables can explain the average firm size at the metropolitan area level.

This hypothesis does not seek to explain why the education level or age characteristics differ across metropolitan areas. Presumably these variables are themselves a function of historical 
variables (like the existence of universities before 1940 as in Moretti, 2004) or temperature. If demographics are found to be important, then future work can use more exogenous variables as instruments for demographics.

Hypothesis \# 2: A Culture of Entrepreneurship

A second hypothesis is that cities tend to have an entrepreneurial zeitgeist that then infects their citizenry. According to this view, there are some places that are intrinsically full of new ideas and a spirit of change. Alternatively, there are other places where tradition and old social structures rule.

In a sense, this model argues that there are positive social spillovers from entrepreneurship that generate high degrees of variation across space (as in Glaeser et al. 1992). If one person's decision to start a new firm makes it more likely that his neighbor will also become an entrepreneur, this could create a cascade within the city and variation across cities. In some cases, these complementarities may work through easy-to-understand economic processes. If there are fixed costs in the provision of venture capital or inputs, then the positive spillover may work through inducing more of these needed inputs. In other cases, the positive complementarity may work through more ephemeral channels.

One critical issue is the extent to which this positive spillover works across industries. If we believe that there is a general urban tendency towards entrepreneurship, then this can be tested by looking at the impact of being around other entrepreneurial industries in the city. To measure this, I create a predicted entrepreneurship measure by using a measure

$\sum_{j \neq i} \frac{\text { Emp }_{j, M S A} * \text { Entrepreneurship }_{j, U S A}}{\text { Emp }_{M S A} * \text { Entrepreneurship }_{U S A}}$, where $E m p_{j, M S A}$ is the employment in industry $\mathrm{j}$ in the MSA, Emp $p_{M S A}$ is the total employment in the MSA, Entrepreneurship $p_{j, U S A}$ is an 
entrepreneurship measure (either the self-employment rate or average firm size) for industry $\mathrm{j}$ across the entire U.S. and Entrepreneurship $p_{U S A}$ is the same entrepreneurship measure across all industries in the county.

This measure takes the average of the entrepreneurship measures weighted by the industrial employment outside of the industry in question. In other words, it is the predicted level of entrepreneurship based on the industry mix in the city and the entrepreneurship measure for that industry in the country as a whole. I will use both the self-employment measure and the average firm size measure for this input.

As there is some question about whether or not this "spirit of entrepreneurship" travels far across industrial borders, I will calculate this measure both for the country as a whole and within specific industry groups, i.e. 1-digit NAICS industries. I will also estimate this spirit of entrepreneurship using both the self-employment rate and average firm size data.

\section{Hypothesis \# 3: Inputs for New Firms}

A third hypothesis is that different metropolitan areas are endowed with the inputs that are needed to produce new firms. Chinitz himself emphasized the importance of decentralized inputs in making things easier for entrepreneurship. I will focus on three inputs that are needed by new firms forming in particular industries.

One of the inputs into entrepreneurship that has received the most attention is venture capital. These high risk lenders have certainly played a major role in a large number of new start-ups. Naturally, one can question the extent to which geographic distance makes it difficult to get financing. Venture capitalists have been known to get on airplanes. As a result, I think that while there is no question that venture capital matters to new start-ups, there is a question about whether local venture capital is needed for local entrepreneurship. 
Unfortunately, finding exogenous variation in venture capital is far from easy. I will take the easier step of just looking at whether measures of venture capital (at https://www.pwcmoneytree.com/MTPublic/ns/index.jsp) correlate with self-employment and firm size at the metropolitan area level. I will also ask whether this financing has more of an effect for manufacturing industries with more capital requirement.

While venture capital is a particularly obvious input, firms also purchase inputs and hire labor, and supplies of inputs and labor also differ across metropolitan areas. Dumais, Ellison and Glaeser (1997) look at the connection between measures of input, labor supply and new firm births. Our input measure is Input $_{i, M S A}=\sum_{j \neq i} \frac{E m p_{j, M S A}}{E m p_{M S A}}$ Input $_{j i}$ where Input $t_{j i}$ describes the share of industry i's inputs that are bought from industry $\mathrm{j}$.

Chinitz emphasized the role of small decentralized input suppliers, rather than large centralized firms. He argued that the overall level of entrepreneurship depended on the presence of many small firms that can readily supply new start-ups. To capture this, I use an alternative input measure Chinitz $_{i, M S A}=\sum_{j \neq i} \frac{\text { Firms }_{j, M S A}}{E m p_{j, M S A}} \frac{E m p_{j, M S A}}{E m p_{M S A}} \operatorname{Input~}_{j i}=\sum_{j \neq i} \frac{\text { Firms }_{j, M S A}}{E m p_{M S A}}$ Input $_{j i}$. This measure captures the number of firms that supply this industry's needs in this metropolitan area.

My third measure of inputs focuses on the labor supply. In this case, I start with Share ${ }_{o i}$, which is the share of industry i's in occupation o. I then use the distribution of occupations within the metropolitan area to define Labor Mix $x_{i, M S A}=\sum_{o} \frac{E_{0} m_{o, M S A}}{E m p_{M S A}}$ Share $_{o j}$, which represents the preponderance of employment in occupation o in this particular metropolitan area. 
In all cases, these measures are endogenous to the level of entrepreneurship. I believe that this problem is less severe when looking at our entrepreneurship measure than it would be if I was examining the overall employment in the industry. Nonetheless, if these factors do matter, endogeneity would generally mean that the estimated coefficients may be biased upwards.

\section{Hypothesis \# 4: Customers}

A final hypothesis is that entrepreneurship is driven by local customer needs. There are at least three reasons why customers would tend to increase the overall amount of entrepreneurship. First, the entrepreneurs may start firms to cater to this customer base. This is surely the most natural reason for a connection between entrepreneurship and customer base. I suspect that this is particular important for industries like health services. There are surely more doctors in West Palm Beach because of their retiree customers.

A second reason why customers might matter for entrepreneurship is that innovators often learn by connecting with their customer base. Porter (1990) emphasizes this connection in the Sassuolo ceramics industry. There is also evidence that this chain of information flow operates in the software industry as well (Saxenian, 1994). A third reason why customers might matter is that erstwhile customers may have eventually become entrepreneurs themselves.

The most basic demand side measure is $\operatorname{Demand}_{i, M S A}=\sum_{j \neq i} \frac{E m p_{j, M S A}}{\operatorname{Emp}_{M S A}}$ Output $_{i j}$, where Output $_{i j}$ represents the share of output in industry i that is sold to industry $\mathrm{j}$. This is the measure used by Dumais, Ellison and Glaeser (1997) and it represents the extent to which employment in this area is skewed towards industry where industry i generally sells its goods.

I will also consider two alternative measures of consumer demand. First, I will use an interaction of population and retail trade to examine whether industries that sell directly to the public have more entrepreneurship in cities that are bigger, relative to sectors that don't sell directly to the 
public. Second, I will specifically look at whether entrepreneurs that take care of the elderly specifically locate in places with an older population.

\section{The Correlates of Entrepreneurship across Metropolitan Areas}

I now turn to three empirical exercises which are meant to assess the relative importance of these different theories in explaining the level of entrepreneurial activity across American cities. I first look at self-employment rates using individual data from the 2000 Census. I then turn to average firm size. Finally, I reproduce results from Dumais, Ellison and Glaeser (1997) on growth in new establishments using the Longitudinal Research Database.

\section{Self-Employment Evidence}

Table 5 includes regressions where self-employment is regressed on individual characteristics, including dummies for gender, eight age categories and five education categories. The data includes only employed adults between 25 and 65 . The regression also includes industry dummies in all regressions, and the standard errors are clustered at the metropolitan area level. The results are from a linear probability model. The coefficients are quite similar if a Probit model is used instead; the linear probability model is used to facilitate correcting the standard errors.

The first regression (1) includes only the industry dummies and the individual demographic controls. Men are about 3.7 percent more likely to be self-employed than women. Selfemployment rates rise steadily with age, where 60-65 year olds are 8.1 percent more likely to be self-employed than 25-30 year olds. The relationship with education is also monotonic. High school dropouts are 6.9 percent less likely to be self-employed than college graduates. Education and age are associated with both human capital and assets, both of which are useful inputs when starting your own business. 
How well can individual characteristics and industries explain the self-employment rates across space? The overall r-squared of the regression is 7 percent, which means that these characteristics can only explain 7 percent of the individual variation in self-employment. To calculate the extent to which metropolitan area variation in self-employment can be explained by individual characteristics, I compare the raw standard deviation of self-employment rates across areas with the self-employment rates correcting for individual characteristics. I form these corrected rates by taking the residuals the first regression and averaging them at the metropolitan area level.

The raw standard deviation of self-employment rates is .013. The standard deviation of the averaged residual is .009 . Squaring these standard deviations to get variances, I find that the variance of the corrected rates is slightly less than one-half of the variance of uncorrected rates. In other words, correcting for individual characteristics and industries explains one-half of the variation in self-employment rates across space. Nothing that I will do subsequently will have the same ability to explain the variation in self-employment rates across space. This means that the most important indicators of the heterogeneity in self-employment rates across space are the industrial mix of the area and the tendency of some areas to have older people who are more likely to be self-employed.

The second regression (2) looks at the impact of area level characteristics, including city size and the presence of venture capital. The regression shows that the self-employment rate rises significantly with the size of the metropolitan area, but the effect is modest. As the size of the metropolitan area increases by 10 percent, the self-employment rate increases by .09 percentage points. Big cities seem to be moderately friendlier to entrepreneurs. The regression finds little connection between venture capital and the self-employment rate, perhaps because venture capital is targeted towards a small set of industries that have high returns, but don't account for a large share of the total self-employed population. 
This regression includes the logarithm of overall employment in one's industry in the area. The coefficient on this variable is -.008. This suggests that as one's industry becomes more prevalent, the self-employment rates declines by .08 percentage points. High self-employment rates are more prevalent in areas where industries are poorly represented rather than in areas where industries are more common. All subsequent regressions include this control.

This regression also presents a test of the culture of entrepreneurship hypothesis by adding the variable $\sum_{j \neq i} \frac{E^{2 m p_{j, M S A}} * \text { Self }- \text { Employment }_{j, U S A}}{\text { Emp }_{M S A} * \text { Self }- \text { Employment }_{U S A}}$. This variable is a predicted self-employment rate in the city, outside of an individual's industry, based on the industrial mix of the city. In the regression, this measure has a coefficient of .91 and a standard error of .14. People who work in cities which have industries that are prone to be entrepreneurial are more likely to be entrepreneurial themselves.

The magnitude of the coefficient implies that as predicted entrepreneurship outside of one's own industry increases by 10 percent, relative to the U.S. self-employment rate, the probability of being self-employed increases by about 9 percent. The biggest problem in interpreting this result is that the industrial mix of the area may not be endogenous. Areas that have attributes that make them friendlier to self-employment may attract industries that have higher selfemployment rates. As a result, these findings may be compromised by an omitted variables bias, where the omitted variables create a spurious correlation between the predicted self-employment rate and the self-employment in one's own industry.

To address this issue, regression (3) includes metropolitan area fixed effects. Since the overall predicted self-employment rate variable does not differ significantly within the metropolitan area, I instead use the measure calculated within an individual's one digit industry. This regression should be seen, therefore, as testing the hypothesis that people who are in one-digit industries that are particularly oriented towards high self-employment rate activities are more likely to be self-employed. In this case, the coefficient is -.45 and the standard error is .13 . 
People are less likely to be self-employed if the industry mix within their one-digit industry in the city favors self-employment. When I estimate regression (3) without metropolitan area fixed effects, the coefficient remains quite negative and significant.

Since regressions (2) and (3) give us such different results, it is hard to know how to interpret these findings. Regression (2) certainly suggests a strong connection between areas with industries that are oriented towards self-employment and individual self-employment. Regression (3) shows that this does not persist with metropolitan area fixed effects. One interpretation is that regression (2) is driven entirely by omitted area level characteristics. Another interpretation is that the culture of entrepreneurship is not particularly localized to one's own industry. Further work will be needed to differentiate between these two interpretations.

Regression (4) includes our first measures of inputs to entrepreneurship: the measure of presence of industry suppliers, Input $_{i, M S A}=\sum_{j \neq i} \frac{E m p_{j, M S A}}{E m p_{M S A}} I_{n p u}{ }_{j i}$, and the interaction of venture capital with being a capital intensive industry. The input measure has a strong and significant positive effect. As the value of this variable increases by .05, which could signal a transfer of 20 percent of employment from an industry that provide no inputs for industry $i$ to an industry that provides 25 percent of industry i's inputs, then the self-employment rate goes up by slightly over two percent in that industry.

This regression also includes an interaction term between the venture capital measure and being in a high skilled manufacturing industry. This interaction is testing the hypothesis that venture capital particularly matters in that capital intensive sector. I find no evidence of this interaction. In general, the venture capital measures have little correlation with the self-employment rate, so I omit them from future regressions in this table. 
Regression (5) includes our measure of input suppliers who are in small firms, Chinitz $_{i, M S A}=\sum_{j \neq i} \frac{\text { Firms }_{j, M S A}}{\text { Emp }_{M S A}}$ Input $_{j i}$. In this case, there is no effect of this variable. Input suppliers seem to increase self-employment, but the size of these suppliers is not important. Regression (6) includes the labor mix variable Labor Mix ${ }_{i, M S A}=\sum_{o} \frac{E m p_{o, M S A}}{E m p_{M S A}}$ Share $_{o j}$. In this case, more workers lead to less, not more, self-employment in the area.

Regression (7) looks at demand side variables. The basic demand variable Demand $_{i, M S A}=\sum_{j \neq i} \frac{E m p_{j, M S A}}{E m p_{M S A}}$ Output $_{i j} \quad$ has a negative effect. I also look at whether city population has a disproportionate impact on self-employment rates in those industries that cater directly to the public. I find that self-employment rates rise in big cities for retail trade in this regression with metropolitan area fixed effects. I also look at whether self-employment rates rise in the health services industry in those cities with a greater population over the age of 65 . I find that the opposite is true and self-employment rates in the health services industry are actually lower in the cities with a more elderly population.

Regression (8) combines all of our major explanatory variables. The significant variables that are positively associated with self-employment are the input measure and the interaction between city size and retail trade. Beyond that, there is little evidence for the other hypotheses. Suppliers seem to matter, but consumers are less important apart from retail trade. There is certainly evidence (Ellison, Glaeser and Kerr, 2007) that the location of suppliers and workers matters for overall employment in an industry, but there is no evidence that the demand side factors increase the rate of self-employment in the industry. I now turn to regressions on firm size.

Firm Size Correlations 
Table 6 looks at the correlates of firm size across metropolitan areas. Regression (1) looks at average firm size in the metropolitan area as a dependent variable. Regressions (2)-(5) look at average firm size in a metropolitan area in a particular industry as a dependent variable.

In the first regression, I include the basic city demographics, the log of city population and the $\log$ of venture capital spending as explanatory variables. To correct for the industrial mix of the city, I include a control variable $\sum_{j} \frac{E m p_{j, M S A}}{E m p_{M S A}} \frac{F i r m s_{j, U S A}}{E m p_{j, U S A}}$, which is average firm size in the industries in the metropolitan area, weighted by the employment share of each industry in the area. This measure is meant to control for the industrial mix of the metropolitan area.

The first regression shows the basic correlates of firm size in the city as a whole. The industry mix certainly does matter, but it tends to matter less than one-for-one. For every extra person per firm predicted by this measure, the city will have only one quarter of an extra person per firm. This result actually also tends to reject the "culture of entrepreneurship" hypothesis, which would predict that this coefficient would be greater than one because entrepreneurship in one industry should inspire more entrepreneurship in other industries. Under this hypothesis, this would create a social multiplier and a coefficient greater than one.

The demographic variables do not correspond well to the individual level facts about demographics and self-employment. Education is associated with bigger, not smaller, firms. An abundance of people under the age of 40 predicts smaller firms. Only the coefficient on people over the age of 60 supports the previous finding that older people are more entrepreneurial. City size also favors bigger firms. This finding runs in the opposite direction than the self-employment regressions. I do find that venture capital positively predicts small firms. The overall r-squared in this regression is 35 percent. This supports the view that basic demographics can explain a significant amount of the variation across cities. 
In the second regression, I turn to industry-specific measures. Since these regressions are performed at the MSA-industry level, I include both industry and MSA fixed effects. I also include the logarithm of employment in the industry in the MSA. Just as the logarithm of employment is associated with less self-employment, it is also associated with smaller average firm sizes.

In regression (2), I also include the input measure and an interaction of the venture capital measure with high skilled manufacturing. In this case, the interaction works as predicted, as more venture capital is associated with smaller average firm sizes in high skilled manufacturing. The input measure is associated with smaller average firm size, but the effect is small. As this variable increases by .05 , there are .0015 fewer workers per firm in the industry in the metropolitan area. Still, this confirms the view that there is more entrepreneurship in places where inputs are more readily available.

The third regression includes the Chinitz measure, which captures the firm size in industries that supply inputs in the area. The Chinitz measure is quite significant statistically. If the number of firms per worker increases by .1 in every industry that supplied this industry, then the expected number of workers per firm in this industry would decrease by -.03. The presence of many suppliers doesn't impact self-employment, but it does increase the number of independent firms.

The fourth regression includes the labor mix variable, which has a significant negative impact on average firm size. If this variable increases by .05 , which indicates that 20 percent of all employment moves from occupations that provide none of the workers for this industry into occupations that provide 25 percent of the workers for this industry, then the predicted number of workers per firm declines by -.35 .

In regression (5), I include the demand-side measures. Though more demand is associated with smaller firms, the effect of this variable is quite modest. As this variable increases by .05, 
workers per firm declines by -.002 . The other demand measures- the interaction between retail trade and population and the interaction between health and the share of the population that is older-have no impact.

In regression (6), I include all of the major explanatory variables, and their coefficients are relatively stable, except for the Chinitz variable which switches signs. All four variables remain statistically significant, but the labor mix variable and the Chinitz variable are the most important measures. Overall, input measures and demand do all seem to matter, but the variables that are particularly important for small firms are multiple input suppliers and abundant workers.

Evidence from the Longitudinal Research Database

Table 7, my final table, is taken from Dumais, Ellison and Glaeser (1997), and contains evidence on new establishment creation in the Longitudinal Research Database. The advantage of this data is that I am able to look at creation of new plants over time. Unfortunately, the restricted nature of this data means that I have not been able to update these results or change the regressions. This data includes only data from manufacturing and it represents a panel with linked establishment level data between 1972 and 1992.

My regressions here are of the form:

(4) $\log \left(1+\Delta E m p_{\text {ist }}\right)=\beta_{1}$ Input $+\beta_{2}$ Demand $+\beta_{3}$ Labor Mix + Other Controls

The variable $\log \left(1+\Delta E m p_{i s t}\right)$ reflects the increase in employment due to new establishments in industry i, place s, and time period t. We distinguish between new firm establishments and old firm establishments. New firm establishments are those establishments that are not part of the same firm as any other establishment in the manufacturing database. Old firm establishments include those establishments that are part of the same firm as other firms in the database. The new firm employment growth is probably closer to capturing the amount of entrepreneurial growth in the area. 
The input and demand measures are the same as those described above. The labor mix variable, however, is different and in this case is based on the industrial structure of the area. Labor mix is here defined as Labor Mix $\operatorname{Mi,MSA}=-\sum_{o}\left(\frac{E m p_{i, o, U S A}}{E m p_{i, U S A}}-\sum_{j \neq i} \frac{E m p_{j, s, M S A}}{E m p_{M S A}-E m p_{j, M S A}} \frac{E m p_{j, o, U S A}}{E m p_{j, U S A}}\right)^{2}$ which is defined as the difference between the occupation pattern in the industry in the U.S. as a whole and the average occupation pattern of the other industries in the metropolitan area.

The regression also includes a control for integration and technology flows. Integration represents the tendency of other firms in that industry to be co-owned with other firms from the other industries in the metropolitan area. The integration measure is Integration $_{i, M S A}=\sum_{j \neq i} \frac{E^{E m p_{j, M S A}}}{\operatorname{Emp}_{M S A}} \frac{C o-\text { Owned }_{j i, U S A}}{E m p_{i, U S A}}$, where Co-Owned ${ }_{j i, U S A}$ measures the amount of employment in plants in industry $i$ that are in multi-establishment firms with plants in both industry $\mathrm{i}$ and industry $\mathrm{j}$. We specifically eliminate co-ownership that is due to input-output linkages and the hope is that this measure captures more intangible reasons for connections across industries. Our measure of technology flows uses an input-output chart for patents and attempts to measure the intellectual connections between different industries, and so equals Techflow $_{i, M S A}=\sum_{j \neq i} \frac{\text { Emp }_{j, M S A}}{\text { Emp }_{M S A}} \frac{\text { Citiations }_{j i, U S A}}{\text { Citiations }_{j, U S A}}$, where the citations measures give us that share of all patent citations made by innovators in industry $\mathrm{j}$ that come from industry $\mathrm{i}$. The source for this data is Scherer (1984).

I also control for the general growth in that industry and that area; there are MSA, industry and year fixed effects. All of the measures have been normalized to have mean zero and standard deviation of one. The first three regressions use metropolitan area level data and the last three regressions use state level data. 
In the first regression, we find no positive correlations between new firm employment growth and both input suppliers. The demand measure has a weak positive effect. A one standard deviation increase in this variable is associated with a .02 log point increase in new firm plant birth employment. The labor mix variable is much more powerful. A one standard deviation increase in this variable is associated with a .18 log point increase in new firm plant birth employment. The integration measure is the second most powerful variable in the regression, after labor mix. A one standard deviation increase in this variable is associated with a $.08 \log$ point increase in employment growth. The technology flow variable is insignificant.

Regression (2) tests two related hypotheses. First, labor mix will be more important in more volatile industries. According to this hypothesis, the willingness of workers to take a chance on a new firm depends on the presence of many other employers with whom they could potentially work. The labor fix variable can be seen as measuring the extent of local demand for firms in industry i. The second hypothesis suggests that integration measures something about information spillovers across industries, and that these are more important for more skilled workers.

Regression (2) uses the closure rate of firms in this industry as a proxy for volatility. The importance of the labor mix variable is higher in those industries with a higher closure rate. The integration measure is not particularly higher for those industries with more college educated workers.

Regression (3) repeats regression (1) using employment growth due to plant birth, in cases where plants are co-owned with other plants in the LRD. The results are broadly similar, although in this case the presence of input suppliers becomes marginally more important. The importance of labor mix falls somewhat, but this variable remains the most important one in the regression. A comparison of regression (3) and (1) suggests at least that labor mix may be more important for new plant start-ups than for existing firms starting new plants in an area. 
Regressions (4)-(6) repeat regressions (1)-(3) using states rather than metropolitan areas as the units of analysis. At the state level, the importance of labor mix rise to .43 in regression (4). Both input and demand measures are statistically significant, but they are about one-tenth the size of the labor mix variable. Regression (5) shows that the interactions are insignificant at the state level. Regression (6) shows that labor mix is again far less important for old firm plant birth and that input suppliers have become more important.

Table 7 provides us with a different view of entrepreneurship by looking exclusively within manufacturing and looking at the amount of new employment in an area associated with new plant births. The results do look different from the other work. The presence of firms that use the same type of labor seems like the crucial aspect for the location of these new manufacturing plants. Input suppliers and customers matter much less. The integration measure also has some significance, but interpreting this measure is far from easy.

\section{Conclusion}

This paper has documented a series of stylized facts about entrepreneurship over space. I have used average firm size and the self-employment rate as my measures of entrepreneurship. Both of these measures have their problems, but I believe that they certainly capture something about the level of entrepreneurship in an area. Moreover, both of these measures predict urban success at the metropolitan area level. The number of workers per firm is also strongly negatively associated with growth at the industry level within metropolitan areas.

There is a significant amount of heterogeneity in entrepreneurship over space, and this heterogeneity appears more strongly within individual industries than across the economy as a whole. Florida appears to be particularly entrepreneurial, while many Rust Belt metropolitan areas are not. Across individuals, age and schooling both predict entrepreneurship. These demographic variables, and industry sectors, together explain about one-half of the heterogeneity in overall self-employment rates across metropolitan areas. 
I find mixed evidence for the existence of a "culture of entrepreneurship" in a particular metropolitan area. Self-employment rates are higher among individuals who live in metropolitan areas that are filled with particularly entrepreneurial industries. However, this effect does not hold within more narrow industrial categories. As the industry mix changes in a way that predicts one extra worker per firm, the actual number of workers per firm only increases by 25 . As such, there is little evidence for a social multiplier where entrepreneurial industries create abundant entrepreneurs outside of their industries.

One general fact is that these entrepreneurship figures always decline with the concentration of an industry in an area. The number of self-employed workers and the number of firms per worker are higher in areas where industries are less common. This fact can be explained by many factors, including the possibility that entrepreneurs are spread relatively evenly, but in some areas they are more successful. In that case, high levels of employment would be associated with a lower number of entrepreneurs per employee.

The presence of an appropriate workforce is the most powerful predictor of new firm birth (a third measure of entrepreneurship) and small firms. Workers seem to be a crucial input into new businesses. There is no correlation between labor mix and the self-employment rate. A measure of the presence of small firms in supplying industries, as suggested by Chinitz (1961), also correlates strongly with the presence of small firms. The self-employment rate is most strongly associated with input suppliers, but that variable is more weakly connected with either of the other two measures of entrepreneurship. The presence of customers seems to be relatively unimportant in all of the regressions.

Overall, these results are, at best, suggestive. There are no forms of exogenous variation and there are many potential explanations for each one of the facts. However, they do point to the paramount importance of labor supply in driving entrepreneurship. Skilled, older people are much more likely to be entrepreneurs, and entrepreneurship increases in areas with an 
appropriate labor force, presumably because these people provide both workers and entrepreneurs. These results suggest that pro-entrepreneurship policies might focus particularly on attracting the right type of workers. 


\section{References}

Blanchflower, D.G. and A. J. Oswald (1998), “What Makes an Entrepreneur?” Journal of Labor Economics, 16 (1), 26-60.

Chinitz, B. (1961). "Contrasts in Agglomeration: New York and Pittsburg," American Economic Review, 51 (2), 279-289.

Dumais, G., G. Ellison and E.L. Glaeser (1997), "Geographic Concentration As A Dynamic Process," NBER Working Paper \#6270.

Ellison, G., E.L. Glaeser, and W. Kerr (2007), "What Causes Industry Agglomeration? Evidence from Coagglomeration Patterns," NBER Working Paper \#13068.

Evans, D.S., and B. Jovanovic (1989), “An Estimated Model of Entrepreneurial Choice Under Liquidity Constraints," Journal of Political Economy, 97 (4), 808-827.

Glaeser, E.L., H. Kallal, J.A. Scheinkman, A. Shleifer (1992); “Growth in Cities," The Journal of Political Economy, 100 (6), 1126-1152.

Miraky, W. (1994), “The Firm Product Cycle,” MIT mimeograph.

Moretti, E. (2004), "Estimating the Social Return to Higher Education: Evidence from Longitudinal and Repeated Cross-Sectional Data," Journal of Econometrics, 121 (1-2), 175-212.

Porter, M.E. (1990), The Competitive Advantage of Nations, New York:Free Press.

Saxenian, A. (1994), Regional Advantage: Culture and Competition in Silicon Valley and Route 128, Cambridge, Mass.:Harvard University Press.

Scherer, F.M. (1984), "Using Linked Patent Data and R\&D Data to Measure Technology Flows," in Z. Griliches (ed), R \& D, Patents and Productivity, Chicago:University of Chicago Press. 


\section{TABLE 1 \\ Share of U.S. Employment by Industry}

\begin{tabular}{lccc}
\hline \hline & $\begin{array}{c}\text { Share of Total } \\
\text { U.S. }\end{array}$ & $\begin{array}{c}\text { Percent of Employees } \\
\text { Employment }\end{array}$ & $\begin{array}{c}\text { Share of Total U.S. Self- Employed Within } \\
\text { Employment } \\
\text { the Industry }\end{array}$ \\
Mining, Utilities, and Construction & $8.28 \%$ & $15.36 \%$ & $9.81 \%$ \\
Low Skilled Manufacturing & $11.45 \%$ & $5.54 \%$ & $2.56 \%$ \\
High Skilled Manufacturing & $7.14 \%$ & $1.16 \%$ & $0.86 \%$ \\
Wholesale Trade and Transportation & $9.94 \%$ & $9.77 \%$ & $5.20 \%$ \\
Retail Trade & $11.05 \%$ & $11.58 \%$ & $5.54 \%$ \\
Low Skilled Information Services & $14.90 \%$ & $13.35 \%$ & $4.74 \%$ \\
High Skilled Information Services & $12.54 \%$ & $19.56 \%$ & $8.25 \%$ \\
Education, Health, and Social Services & $13.77 \%$ & $9.89 \%$ & $3.80 \%$ \\
Entertainment, Accommodation, and Food Services & $6.22 \%$ & $6.71 \%$ & $5.70 \%$ \\
Other Services & $4.71 \%$ & $7.08 \%$ & $7.96 \%$ \\
& & & \\
\end{tabular}

Notes:

(1) Share of Total U.S. Employment=(Number Employed in Industry)/(Total Employed)

(2) Share of Total U.S. Self-Employment=(Number Self Employment in Industry)/(Total Self Employed)

(3) Percent of Employees Self Employed Within the Industry=(Number Self Employed in Industry)/(Number Employed in Industry)

(4) Data is microlevel 2000 Census data, from the Integrated Public Use Microdata Series (IPUMS) at http://usa.ipums.org/usa/. Steven Ruggles, Matthew Sobek, Trent Alexander, Catherine A. Fitch, Ronald Goeken, Patricia Kelly Hall, Miriam King, and Chad Ronnander. Integrated Public Use Microdata Series: Version 3.0 [Machine-readable database]. Minneapolis, MN: Minnesota Population Center [producer and distributor], 2004.

(5) Industry divisions are taken using the divisions presented on the IPUMS website at http://usa.ipums.org/usa/volii/indcross.shtml, based on each establishment's 1997 NAICS code. Certain categories are aggregated, dropped or divided as described in notes (6), (7) and (8).

(6) Wholesale trade and transportation is made up of those codes of the form 42-- or 48--. Mining, utilities, and construction corresponds to the codes 21--, 22--, and 23--. Information services covers the NAICS codes that begin with 51-56 and includes Information and Communications; Finance, Insurance, Real Estate, Rental and Leasing; Professional, Scientific, Management, Administrative, and Waste Management Services.

(7) Observations for agriculture, forestry, fishing, and hunting (NAICS code 1---), public administration, and active duty military (NAICS codes 9---) are dropped during the analysis. The unemployed are also are also dropped.

(8) The Manufacturing category is divided by skill level in the following way. The level of skill within the broad Manufacturing industry is determined first by calculating the mean percentage of workers with a bachelor's degree or higher over the entire industry. Then, the mean percentage of workers with a bachelor's degree is calculated for each detailed sub-industry within the broad Manufacturing industry category. If a sub-industry of Manufacturing has a higher mean level of bachelor degrees than the average over the entire Manufacturing industry, then it is classified as a High Skilled Manufacturing industry. If it has a lower mean level of bachelor degrees, it is classified as Low Skilled Manufacturing. The same procedure is used to create the High Skilled and Low Skilled Information Services categories. 


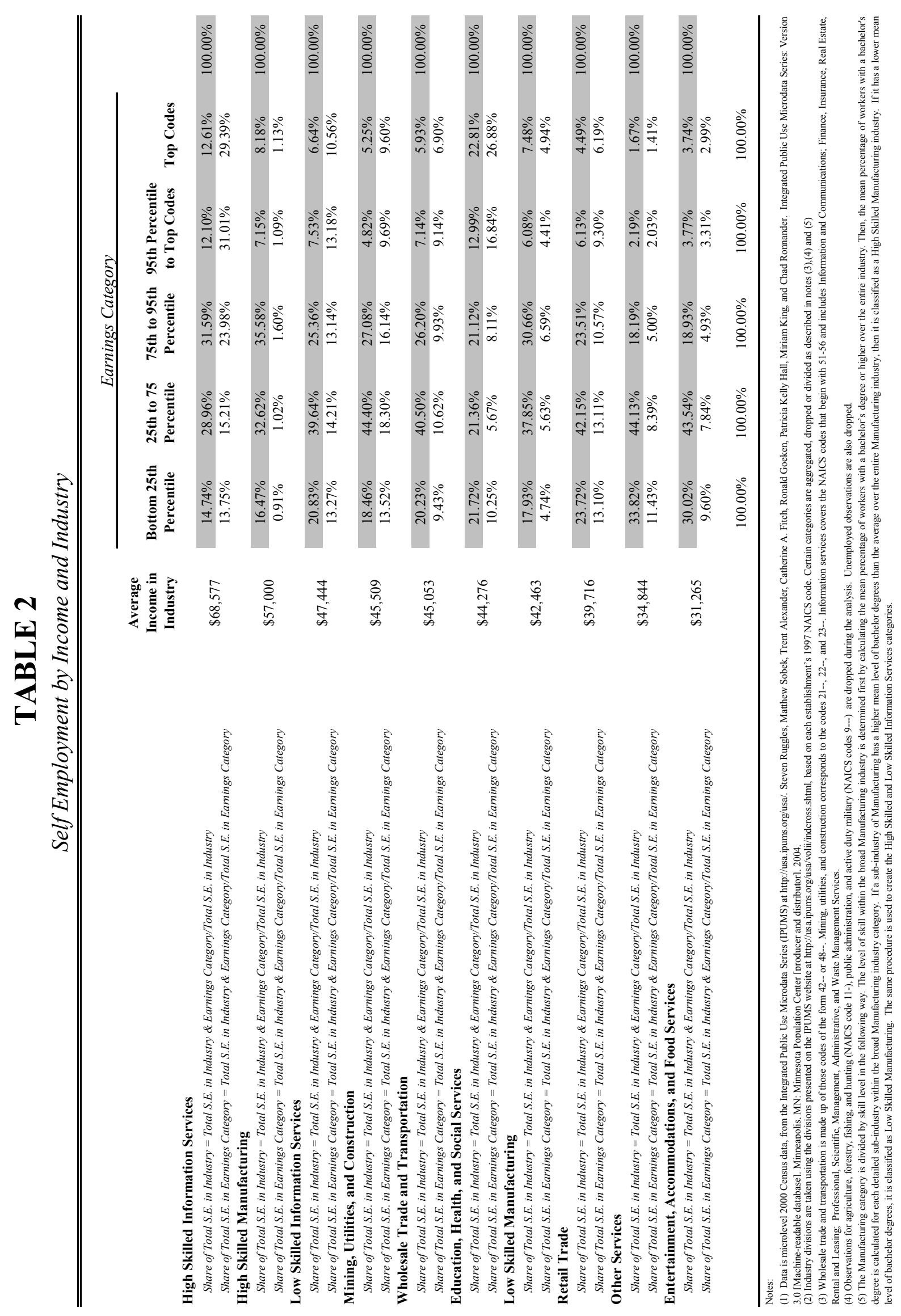


TABLE 3

Shares of Self Employment by MSA

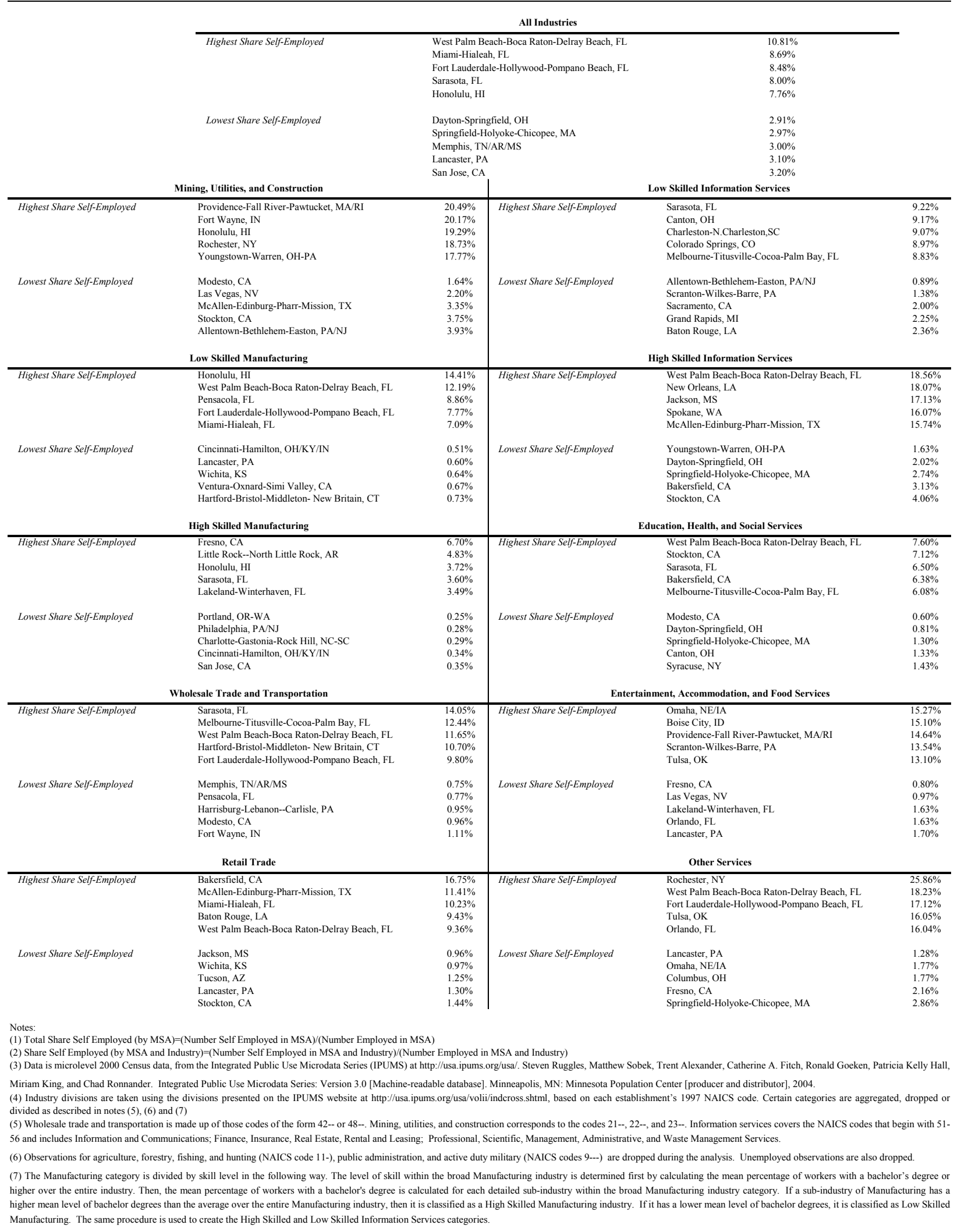




\section{TABLE 4}

Shares of Self Employment by Industry: Correlations

(1)

\begin{tabular}{|c|c|}
\hline \multicolumn{2}{|c|}{$\begin{array}{l}\text { Share of Overall Self Employment (All } \\
\text { Industries) Correlated With: }\end{array}$} \\
\hline $\begin{array}{l}\text { Self Employment } \\
\text { Rate by Industry }\end{array}$ & $\begin{array}{c}\text { Share of Total Self } \\
\text { Employed in } \\
\text { Industry }\end{array}$ \\
\hline 0.4179 & -0.1828 \\
\hline 0.3707 & -0.1732 \\
\hline-0.0374 & -0.2836 \\
\hline 0.3501 & -0.1343 \\
\hline 0.6118 & 0.0802 \\
\hline 0.6607 & 0.0508 \\
\hline 0.6253 & 0.0142 \\
\hline 0.5032 & -0.0765 \\
\hline 0.6377 & 0.1437 \\
\hline 0.648 & 0.1722 \\
\hline
\end{tabular}

Education, Health, and Social Services

Entertainment, Accommodations, and Food Services

High Skilled Manufacturing

Low Skilled Manufacturing

High Skilled Information Services

Low Skilled Information Services

Mining, Utilities, and Construction

Other Services

Retail Trade

Wholesale Trade and Transportation
(2)

(3)

(4)

\begin{tabular}{cc}
$\begin{array}{c}\text { Share of Overall Self } \\
\text { Employment (All } \\
\text { Industries) Correlated } \\
\text { With Self Employment } \\
\text { by Industry (\$75,000+ } \\
\text { Salaries) }\end{array}$ & $\begin{array}{c}\text { Firm Size } \\
\text { Correlated With } \\
\text { Self Employment } \\
\text { Rate by Industry }\end{array}$ \\
\hline 0.3137 & -0.5175 \\
0.1904 & -0.408 \\
0.2553 & -0.5849 \\
0.2789 & -0.5842 \\
0.6055 & -0.4839 \\
0.4984 & -0.1993 \\
0.2907 & -0.3861 \\
-0.2071 & -0.6832 \\
0.4986 & \\
0.4362 &
\end{tabular}

\footnotetext{
Notes:

(1) Column (1) is Correlation of (Self Employed in Industry "x")/(Total Employment in Industry "x") and (Self Employed All Industries)/(Total Employment All Industries)

(2) Column (2) is Correlation of (Self Employed in Industry "x")/(Total Self Employment) and (Self Employed All Industries)/(Total Employment All Industries)

(3) Column (3) is Correlation of (Self Employed in Industry "x" with Salary Over \$75,000)/(Total Employment in Industry "x" with Salary Over \$75,000) and (Self Employed with Salary Over $\$ 75,000$ All Industries)/(Total Employment with Salary Over \$75,000 All Industries)

(4) Column (4) is Correlation of (Self Employed in Industry "x")/(Total Employment in Industry "x") and Average Firm Size in 2000

(5) Self Employment data is from the 2000 Census microdata, found in the Integrated Public Use Microdata Series (IPUMS) at http://usa.ipums.org/usa/. Steven Ruggles, Matthew Sobek, Trent Alexander, Catherine A. Fitch, Ronald Goeken, Patricia Kelly Hall, Miriam King, and Chad Ronnander. Integrated Public Use Microdata Series: Version 3.0 [Machine-readable database]. Minneapolis, MN: Minnesota Population Center [producer and distributor], 2004.

(6) For the self-employment data, industry divisions are taken using the divisions presented on the IPUMS website at http://usa.ipums.org/usa/volii/indcross.shtml, based on each establishment's 1997 NAICS code. Certain categories are aggregated, dropped or divided as described in notes (7), (8) and (9).

(7) For the self-employment data, wholesale trade and transportation is made up of those codes of the form 42-- or 48--. Mining, utilities, and construction corresponds to the codes 21--, 22--, and 23--. Information services covers the NAICS codes that begin with 51-56 and includes Information and Communications; Finance, Insurance, Real Estate, Rental and Leasing; Professional, Scientific, Management, Administrative, and Waste Management Services

(8) For the self-employment data, observations for agriculture, forestry, fishing, and hunting (NAICS code 11-), public administration and active duty military (NAICS codes 9---) are dropped during the analysis. Unemployed observations are also dropped.

(9) For the self-employment data, the Manufacturing category is divided by skill level in the following way. The level of skill within the broad Manufacturing industry is determined first by calculating the mean percentage of workers with a bachelor's degree or higher over the entire industry. Then, the mean percentage of workers with a bachelor's degree is calculated for each detailed sub-industry within the broad Manufacturing industry category. If a sub-industry of Manufacturing has a higher mean level of bachelor degrees than the average over the entire Manufacturing industry, then it is classified as a High Skilled Manufacturing industry. If it has a lower mean level of bachelor degrees, it is classified as Low Skilled Manufacturing. The same procedure is used to create the High Skilled and Low Skilled Information Services categories.

(10) Firm Size data is calculated using the 2000 County Business Patterns at www.census.gov/csd/susb/ussect03.xls
} 


\section{TABLE 5}

\section{Self-Employment Regressions}

\begin{tabular}{|c|c|c|c|c|c|c|c|c|}
\hline & \multicolumn{8}{|c|}{ Dependent Variable: Self Employment Indicator ( 0 or 1$)$} \\
\hline & (1) & (2) & (3) & (4) & (5) & (6) & (7) & (8) \\
\hline Predicted Self Employed - 1 & & $\begin{array}{c}0.909 \\
(0.145)\end{array}$ & & & & & & \\
\hline Log of Venture Capital per Capita (State Level) & & $\begin{array}{l}-0.003 \\
(0.000)\end{array}$ & & & & & & \\
\hline Log of Population in the MSA & & $\begin{array}{c}0.009 \\
(0.001)\end{array}$ & & & & & & \\
\hline Predicted Self Employed - 2 & & & $\begin{array}{c}-0.445 \\
(0.133)\end{array}$ & & & & & \\
\hline Log of VC/capita Interacted with High Skilled Info Services & & & & $\begin{array}{c}-0.004 \\
(0.001)\end{array}$ & & & & \\
\hline Input Measure & & & & $\begin{array}{c}0.422 \\
(0.054)\end{array}$ & & & & $\begin{array}{c}0.470 \\
(0.058)\end{array}$ \\
\hline Chinitz Measure (see Note) & & & & & $\begin{array}{l}.0154 \\
(.070)\end{array}$ & & & $\begin{array}{c}0.012 \\
(0.069)\end{array}$ \\
\hline Labor Mix Measure & & & & & & $\begin{array}{c}-0.018 \\
(0.004)\end{array}$ & & $\begin{array}{l}-0.018 \\
(0.004)\end{array}$ \\
\hline Demand & & & & & & & $\begin{array}{c}-0.059 \\
(0.078)\end{array}$ & $\begin{array}{l}-0.301 \\
(0.084)\end{array}$ \\
\hline Log of Population Interacted with Retail Trade & & & & & & & $\begin{array}{c}0.004 \\
(0.001)\end{array}$ & $\begin{array}{c}0.003 \\
(0.001)\end{array}$ \\
\hline Share of Population over 65 Interacted with Health Services & & & & & & & $\begin{array}{l}-0.112 \\
(0.028)\end{array}$ & $\begin{array}{c}-0.102 \\
(0.028)\end{array}$ \\
\hline Log Employment in Industry in MSA & & $\begin{array}{c}-0.008 \\
(0.001)\end{array}$ & $\begin{array}{c}-0.008 \\
(0.001)\end{array}$ & $\begin{array}{c}-0.01 \\
(0.001)\end{array}$ & $\begin{array}{c}-0.008 \\
(0.001)\end{array}$ & $\begin{array}{c}-0.007 \\
(0.001)\end{array}$ & $\begin{array}{c}-0.008 \\
(0.001)\end{array}$ & $\begin{array}{l}-0.009 \\
(0.001)\end{array}$ \\
\hline Male & $\begin{array}{c}0.037 \\
(0.001)\end{array}$ & $\begin{array}{c}0.037 \\
(0.001)\end{array}$ & $\begin{array}{c}0.037 \\
(0.001)\end{array}$ & $\begin{array}{c}0.036 \\
(0.001)\end{array}$ & $\begin{array}{c}0.037 \\
(0.001)\end{array}$ & $\begin{array}{c}0.037 \\
(0.001)\end{array}$ & $\begin{array}{c}0.036 \\
(0.001)\end{array}$ & $\begin{array}{c}0.036 \\
(0.001)\end{array}$ \\
\hline 30 to 34 & $\begin{array}{c}0.014 \\
(0.001)\end{array}$ & $\begin{array}{c}0.014 \\
(0.001)\end{array}$ & $\begin{array}{c}0.014 \\
(0.001)\end{array}$ & $\begin{array}{c}0.014 \\
(0.001)\end{array}$ & $\begin{array}{c}0.014 \\
(0.001)\end{array}$ & $\begin{array}{c}0.014 \\
(0.001)\end{array}$ & $\begin{array}{c}0.014 \\
(0.001)\end{array}$ & $\begin{array}{c}0.014 \\
(0.001)\end{array}$ \\
\hline 35 to 39 & $\begin{array}{c}0.033 \\
(0.001)\end{array}$ & $\begin{array}{c}0.033 \\
(0.001)\end{array}$ & $\begin{array}{c}0.033 \\
(0.001)\end{array}$ & $\begin{array}{c}0.033 \\
(0.001)\end{array}$ & $\begin{array}{c}0.033 \\
(0.001)\end{array}$ & $\begin{array}{c}0.033 \\
(0.001)\end{array}$ & $\begin{array}{c}0.033 \\
(0.001)\end{array}$ & $\begin{array}{c}0.033 \\
(0.001)\end{array}$ \\
\hline 40 to 44 & $\begin{array}{c}0.046 \\
(0.001)\end{array}$ & $\begin{array}{c}0.046 \\
(0.001)\end{array}$ & $\begin{array}{c}0.046 \\
(0.001)\end{array}$ & $\begin{array}{c}0.046 \\
(0.001)\end{array}$ & $\begin{array}{c}0.046 \\
(0.001)\end{array}$ & $\begin{array}{c}0.046 \\
(0.001)\end{array}$ & $\begin{array}{c}0.046 \\
(0.001)\end{array}$ & $\begin{array}{c}0.046 \\
(0.001)\end{array}$ \\
\hline 45 to 49 & $\begin{array}{c}0.055 \\
(0.001)\end{array}$ & $\begin{array}{c}0.055 \\
(0.001)\end{array}$ & $\begin{array}{c}0.055 \\
(0.001)\end{array}$ & $\begin{array}{c}0.055 \\
(0.001)\end{array}$ & $\begin{array}{c}0.055 \\
(0.001)\end{array}$ & $\begin{array}{c}0.055 \\
(0.001)\end{array}$ & $\begin{array}{c}0.055 \\
(0.001)\end{array}$ & $\begin{array}{c}0.055 \\
(0.001)\end{array}$ \\
\hline 50 to 54 & $\begin{array}{c}0.063 \\
(0.001)\end{array}$ & $\begin{array}{c}0.063 \\
(0.001)\end{array}$ & $\begin{array}{c}0.063 \\
(0.001)\end{array}$ & $\begin{array}{c}0.062 \\
(0.001)\end{array}$ & $\begin{array}{c}0.063 \\
(0.001)\end{array}$ & $\begin{array}{c}0.063 \\
(0.001)\end{array}$ & $\begin{array}{c}0.062 \\
(0.001)\end{array}$ & $\begin{array}{c}0.062 \\
(0.001)\end{array}$ \\
\hline 55 to 60 & $\begin{array}{c}0.073 \\
(0.002)\end{array}$ & $\begin{array}{c}0.073 \\
(0.002)\end{array}$ & $\begin{array}{c}0.073 \\
(0.002)\end{array}$ & $\begin{array}{c}0.072 \\
(0.002)\end{array}$ & $\begin{array}{c}0.073 \\
(0.002)\end{array}$ & $\begin{array}{c}0.073 \\
(0.002)\end{array}$ & $\begin{array}{c}0.072 \\
(0.002)\end{array}$ & $\begin{array}{c}0.071 \\
(0.002)\end{array}$ \\
\hline 60 to 65 & $\begin{array}{c}0.081 \\
(0.002)\end{array}$ & $\begin{array}{c}0.081 \\
(0.002)\end{array}$ & $\begin{array}{c}0.08 \\
(0.002)\end{array}$ & $\begin{array}{c}0.08 \\
(0.002)\end{array}$ & $\begin{array}{c}0.081 \\
(0.002)\end{array}$ & $\begin{array}{c}0.08 \\
(0.002)\end{array}$ & $\begin{array}{c}0.079 \\
(0.002)\end{array}$ & $\begin{array}{c}0.08 \\
(0.002)\end{array}$ \\
\hline No High School & $\begin{array}{c}-0.069 \\
(0.002)\end{array}$ & $\begin{array}{c}-0.069 \\
(0.002)\end{array}$ & $\begin{array}{c}-0.07 \\
(0.002)\end{array}$ & $\begin{array}{l}-0.068 \\
(0.002)\end{array}$ & $\begin{array}{c}-0.07 \\
(0.002)\end{array}$ & $\begin{array}{c}-0.07 \\
(0.002)\end{array}$ & $\begin{array}{l}-0.067 \\
(0.002)\end{array}$ & $\begin{array}{c}-0.043 \\
(0.001)\end{array}$ \\
\hline Some High School & $\begin{array}{l}-0.058 \\
(0.002)\end{array}$ & $\begin{array}{l}-0.059 \\
(0.002)\end{array}$ & $\begin{array}{l}-0.059 \\
(0.002)\end{array}$ & $\begin{array}{l}-0.056 \\
(0.002)\end{array}$ & $\begin{array}{l}-0.059 \\
(0.002)\end{array}$ & $\begin{array}{l}-0.059 \\
(0.002)\end{array}$ & $\begin{array}{l}-0.056 \\
(0.002)\end{array}$ & $\begin{array}{l}-0.068 \\
(0.002)\end{array}$ \\
\hline High School Graduate & $\begin{array}{l}-0.045 \\
(0.001)\end{array}$ & $\begin{array}{l}-0.045 \\
(0.001)\end{array}$ & $\begin{array}{l}-0.046 \\
(0.001)\end{array}$ & $\begin{array}{l}-0.044 \\
(0.001)\end{array}$ & $\begin{array}{l}-0.045 \\
(0.001)\end{array}$ & $\begin{array}{l}-0.046 \\
(0.001)\end{array}$ & $\begin{array}{l}-0.044 \\
(0.001)\end{array}$ & $\begin{array}{l}-0.028 \\
(0.001)\end{array}$ \\
\hline Some College & $\begin{array}{l}-0.029 \\
(0.001)\end{array}$ & $\begin{array}{l}-0.029 \\
(0.001)\end{array}$ & $\begin{array}{l}-0.029 \\
(0.001)\end{array}$ & $\begin{array}{l}-0.028 \\
(0.001)\end{array}$ & $\begin{array}{l}-0.029 \\
(0.001)\end{array}$ & $\begin{array}{l}-0.029 \\
(0.001)\end{array}$ & $\begin{array}{l}-0.028 \\
(0.001)\end{array}$ & $\begin{array}{l}-0.056 \\
(0.002)\end{array}$ \\
\hline Constant & $\begin{array}{c}-0.033 \\
(0.016)\end{array}$ & $\begin{array}{c}-0.108 \\
(0.018)\end{array}$ & $\begin{array}{c}0.059 \\
(0.021)\end{array}$ & $\begin{array}{c}0.033 \\
(0.018)\end{array}$ & $\begin{array}{c}0.023 \\
(0.019)\end{array}$ & $\begin{array}{c}0.02 \\
(0.018)\end{array}$ & $\begin{array}{c}0.024 \\
(0.018)\end{array}$ & $\begin{array}{c}0.026 \\
(0.019)\end{array}$ \\
\hline Observations & 369,544 & 369,543 & 369,543 & 361,271 & 364,613 & 369,543 & 361,271 & 356,341 \\
\hline$R$-squared & 0.07 & 0.07 & 0.08 & 0.07 & 0.08 & 0.08 & 0.07 & 0.08 \\
\hline
\end{tabular}

Notes:

(1) Standard errors in parenthesis. All regressions include detailed industry fixed effects. Regressions (3)-(8) also include MSA fixed effects. Standard errors in parenthesis and are clustered at the MSA level.

(2) Except for the venture capital measure, data is from 2000 Census microdata, found in the Integrated Public Use Microdata Series (IPUMS) at http://usa.ipums.org/usa/. Steven Ruggles, Matthew Sobek, Trent Alexander, Catherine A. Fitch, Ronald Goeken, Patricia Kelly Hall, Miriam King, and Chad Ronnander. Integrated Public Use Microdata Series: Version 3.0 [Machine-readable database]. Minneapolis, MN: Minnesota Population Center [producer and distributor], 2004; the 2000 County Business Patterns; and the Bureau of Economic Analysis Input-Output tables at httn://www hea onv/industrv/
(3) The "Predicted Self Employed - 1" variable is test of the culture of entrepreneurship hypothesis, predicted self-employment rate in the city, outside of an individual's industry, based on the industrial mix of the city. The "Predicted Self Employed - 2" is a similar measure calculated within an individual's one digit industry. See text for a detailed description of how these variables were calculated. (4) The measure of venture capital used to calculate the "Log of VC/capita Interacted with High Skilled Info Services" variable and the "Log of VC/capita Interacted with High Skilled Info Services" variable is found at https://www.pwcmoneytree.com/MTPublic/ns/index.jsp.

(5) The "Input Measure" variable captures the share of an industry's inputs that are bought from other industries. See text for a detailed description of how this variable was calculated.

(6) The "Chinitz Measure" variable is used to capture the number of firms that supply an industry's needs in this metropolitan area, based on Chinitz's argument that the overall level of entrepreneurship depended on the presence of many small firms that can readily supply new start-ups. See text for a detailed description of how this variable was calculated.

(7) The "Labor Mix Measure" captures the labor mix of an area. See text for a detailed description of how this variable was calculated.

(8) The "Demand" variable captures the demand of other industries for a particular industry's goods. See text for a detailed description of how this variable was calculated. (9) There are two measures of consumer demand, captured with the "Log of Population Interacted with Retail Trade" variable and the "Share of Population over 65 Interacted with Health Services" variable. See text for a detailed description of how these variables were calculated

(10)The coefficient and s.e. on the Chinitz Measure was multiplied by 100 for readability. 


\begin{tabular}{|c|c|c|c|c|c|c|}
\hline & (1) & (2) & (3) & (4) & (5) & (6) \\
\hline & \multicolumn{6}{|c|}{ Dependent Variable } \\
\hline & $\begin{array}{c}\text { Average } \\
\text { Firm Size } \\
\text { in MSA }\end{array}$ & \multicolumn{5}{|c|}{ Average Firm Size in the Industry and MSA } \\
\hline Predicted Firm Size & $\begin{array}{c}0.251 \\
(0.007)\end{array}$ & & & & & \\
\hline Log Venture Capital per Capita (State Level) & $\begin{array}{l}-0.784 \\
(0.007)\end{array}$ & & & & & \\
\hline Share of Population with BA - MSA & $\begin{array}{l}11.017 \\
(0.201)\end{array}$ & & & & & \\
\hline Log of Population - MSA & $\begin{array}{c}0.747 \\
(0.008)\end{array}$ & & & & & \\
\hline Share of Population under 40 - MSA & $\begin{array}{l}-33.010 \\
(0.836)\end{array}$ & & & & & \\
\hline Share of Population over 60 - MSA & $\begin{array}{l}-46.770 \\
(1.098)\end{array}$ & & & & & \\
\hline Log of VC/capita Interacted with High Skilled Manufacturing & & $\begin{array}{l}-1.098 \\
(0.157)\end{array}$ & & & & \\
\hline Input & & $\begin{array}{l}-0.032 \\
(0.001)\end{array}$ & & & & $\begin{array}{l}-0.041 \\
(0.002)\end{array}$ \\
\hline Chinitz & & & $\begin{array}{l}-0.297 \\
(0.012)\end{array}$ & & & $\begin{array}{c}0.326 \\
(0.023)\end{array}$ \\
\hline Labor Mix & & & & $\begin{array}{l}-7.105 \\
(0.126)\end{array}$ & & $\begin{array}{l}-6.911 \\
(0.126)\end{array}$ \\
\hline Demand & & & & & $\begin{array}{l}-0.037 \\
(0.001)\end{array}$ & $\begin{array}{l}-0.019 \\
(0.001)\end{array}$ \\
\hline Log of Population Interacted with Retail Trade & & & & & $\begin{array}{l}-0.287 \\
(0.178)\end{array}$ & \\
\hline Share of Population over 65 Interacted with Health Care & & & & & $\begin{array}{l}-8.322 \\
(8.301)\end{array}$ & \\
\hline Log of Employment in the Industry and MSA & & $\begin{array}{l}23.094 \\
(0.134)\end{array}$ & $\begin{array}{l}22.306 \\
(0.131)\end{array}$ & $\begin{array}{l}24.038 \\
(0.135)\end{array}$ & $\begin{array}{l}22.683 \\
(0.134)\end{array}$ & $\begin{array}{l}25.365 \\
(0.138)\end{array}$ \\
\hline Constant & $\begin{array}{l}36.223 \\
(0.676)\end{array}$ & $\begin{array}{c}-181.509 \\
(4.342)\end{array}$ & $\begin{array}{c}-174.772 \\
(4.348)\end{array}$ & $\begin{array}{c}-230.495 \\
(1.566)\end{array}$ & $\begin{array}{c}-177.316 \\
(4.385)\end{array}$ & $\begin{array}{c}-244.399 \\
(1.596)\end{array}$ \\
\hline Observations & 76119 & 141832 & 141832 & 137620 & 138351 & 137620 \\
\hline R-squared & 0.35 & 0.68 & 0.67 & 0.70 & 0.67 & 0.71 \\
\hline
\end{tabular}

Notes:

(1)Regression (1) looks at average firm size in the metropolitan area as a dependent variable. Regressions (2)-(6) look at average firm size in a metropolitan area in a particular industry as a dependent variable. All regressions include industry fixed effects. Regressions (2)-(6) also include MSA fixed effects. Standard errors in parenthesis and are clustered at the MSA level.

(2) MSA-level demographic data (education, population, age, employment) is from 2000 Census microdata, from the Integrated Public Use Microdata Series (IPUMS) at http://usa.ipums.org/usa/. Steven Ruggles, Matthew Sobek, Trent Alexander, Catherine A. Fitch, Ronald Goeken, Patricia Kelly Hall, Miriam King, and Chad Ronnander. Integrated Public Use Microdata Series: Version 3.0 [Machine-readable database]. Minneapolis, MN: Minnesota Population Center [producer and distributor], 2004.

(3) Firm size data is from the 2000 County Business Patterns, and the Input-Output data is from the tables at the Bureau of Economic Analysis at http://www.bea.gov/industry/.

(4) The "Predicted Firm Size" variable is average firm size in the industries in the metropolitan area, weighted by the employment share of each industry in the area and is used to correct for the industrial mix of the MSA. See text for a detailed description of how this variable was calculated.

(5) The measure of venture capital used to calculate the "Log of VC/capita Interacted with High Skilled Info Services" variable and the "Log of VC/capita Interacted with High Skilled Info Services" variable is found at https://www.pwcmoneytree.com/MTPublic/ns/index.jsp.

(6) The "Input Measure" variable captures the share of an industry's inputs that are bought from other industries. See text for a detailed description of how this variable was calculated.

(7) The "Chinitz Measure" variable is used to capture the number of firms that supply an industry's needs in this metropolitan area, based on Chinitz's argument that the overall level of entrepreneurship depended on the presence of many small firms that can readily supply new start-ups. See text for a detailed description of how this variable was calculated.

(8) The "Labor Mix Measure" captures the labor mix of an area. See text for a detailed description of how this variable was calculated.

(9) The "Demand" variable captures the demand of other industries for a particular industry's goods. See text for a detailed description of how this variable was calculated.

(10) There are two measures of consumer demand captured with the "Log of Population Interacted with Retail Trade" variable and the "Share of Population over 65 Interacted with Health Services" variable. See text for a detailed description of how these variables were calculated.

(11) The coefficient and s.e. on the Chinitz Measure multiplied by 100 for readability. 


\section{Table 7}

\section{Employment Growth due to Births and Closures}

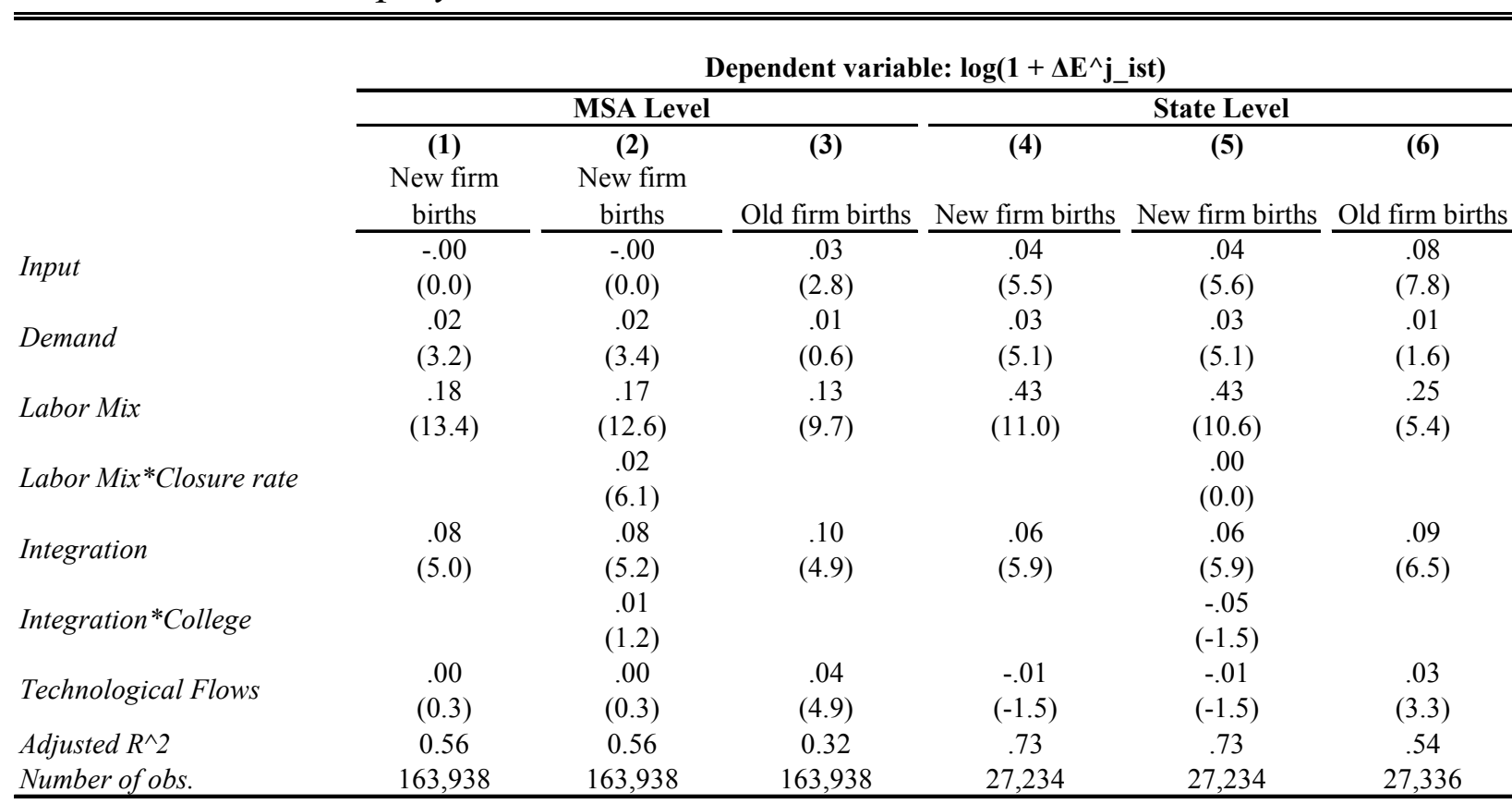

Notes:

(1) The results presented in this table are taken from Dumais, Ellison and Glaeser (1997).

(2) Data is from the Longitudinal Research Database, and includes only data from manufacturing and it represents a panel with linked establishment level data between 1972 and 1992 .

(2) The dependent variable is the increase in employment due to new establishments in industry i, place s, and time period $t$.

(3) The "Input" and "Demand" variables are the same as described in the other tables. The "Labor Mix" variable is defined slightly differently. See text for a detailed description of how these variables were calculated

(4) The "Closure Rate" of firms in this industry interacted with the "Labor Mix" is used as a proxy for volatility.

(5) The "Integration" variable represents the tendency of other firms in that industry to be co-owned with other firms from the other industries in the metropolitan area. See text for a detailed description of how this variable was calculated.

(6) The "College" variable is a measure of the fraction of the employment in the industry that is contained in occupations that would normally require a college degree. It is interacted with the "Integration" variable to create a measure of intellectual spillovers.

(7) The "Technological Flows" variable uses an input-output chart for patents and attempts to measure the intellectual connections between different industries. The source for this data is Scherer (1984). See text for a detailed description of how this variable was calculated.

(8) MSA level regressions include MSA, industry, and year fixed effects. State level regressions include state, industry, and year fixed effects. 


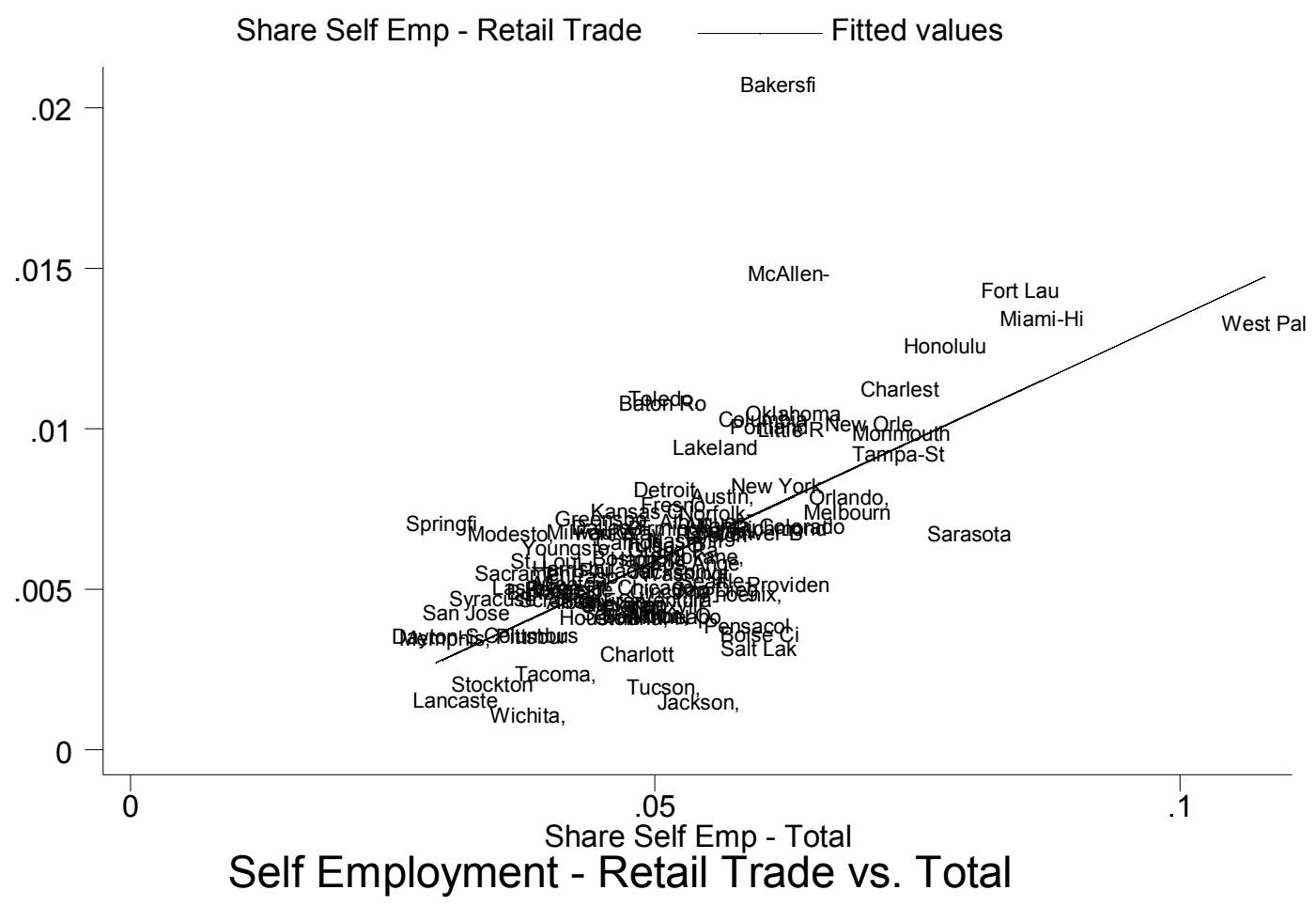

Figure 1

Notes:

(1) Share Self Employment Retail Trade $=($ Self Employed Retail Trade $) /($ Total Employment Retail Trade $)$

(2) Share Self Employment Total=(Self Employed All Industries)/(Total Employment All Industries)

(3) Self Employment data is from the 2000 Census microdata, from the Integrated Public Use Microdata Series (IPUMS) at http://usa.ipums.org/usa/. Steven Ruggles, Matthew Sobek, Trent Alexander, Catherine A. Fitch, Ronald Goeken, Patricia Kelly Hall, Miriam King, and Chad Ronnander. Integrated Public Use Microdata Series: Version 3.0 [Machine-readable database]. Minneapolis, MN: Minnesota Population Center [producer and distributor], 2004.

(4) See notes to Table 4 for further description of the industry categories. 


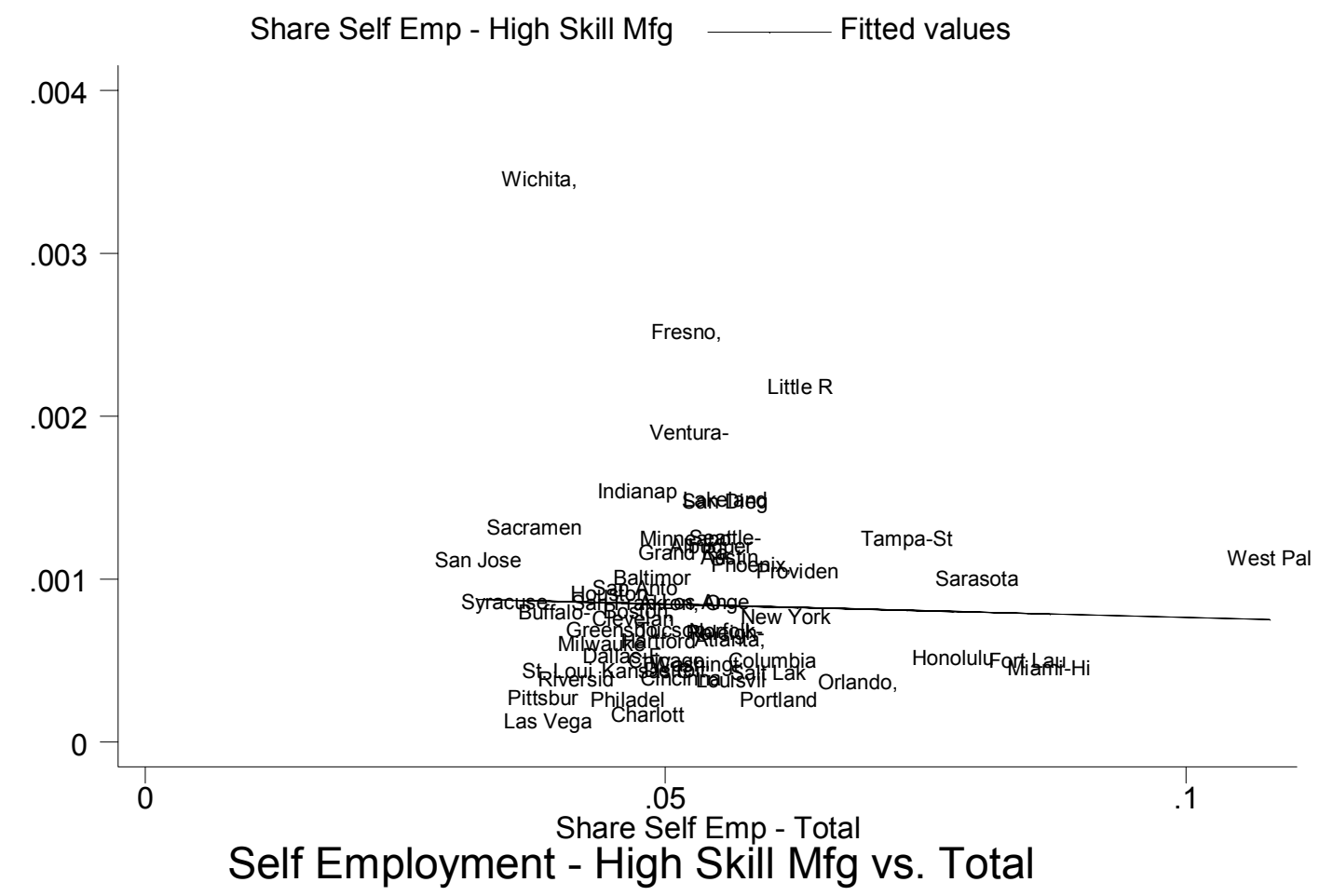

Figure 2

Notes:

(1) Share Self Employment High Skilled Manufacturing=(Self Employed High Skilled Manufacturing)/(Total Employment High Skilled Manufacturing)

(2) Share Self Employment Total=(Self Employed All Industries)/(Total Employment All Industries)

(3) Self Employment data is from the 2000 Census microdata, from the Integrated Public Use Microdata Series (IPUMS) at http://usa.ipums.org/usa/. Steven Ruggles, Matthew Sobek, Trent Alexander, Catherine A. Fitch, Ronald Goeken, Patricia Kelly Hall, Miriam King, and Chad Ronnander. Integrated Public Use Microdata Series: Version 3.0 [Machine-readable database]. Minneapolis, MN: Minnesota Population Center [producer and distributor], 2004.

(4) See notes to Table 4 for further description of the industry categories. 


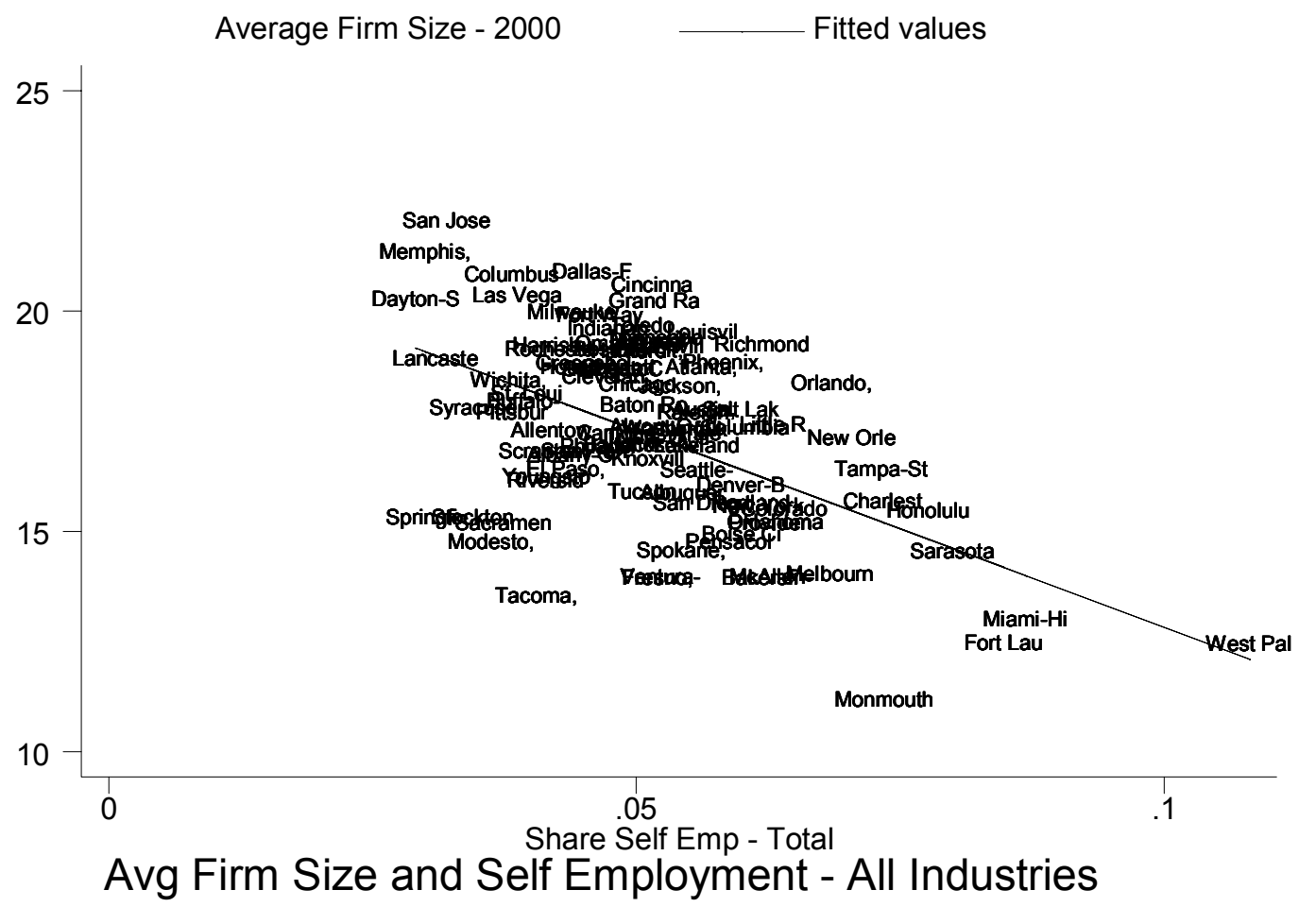

Figure 3

Notes:

(1) Share Self Employment Total=(Self Employed All Industries)/(Total Employment All Industries)

(2) Self Employment data is from the 2000 Census microdata, from the Integrated Public Use Microdata Series (IPUMS) at http://usa.ipums.org/usa/. Steven Ruggles, Matthew Sobek, Trent Alexander, Catherine A. Fitch, Ronald Goeken, Patricia Kelly Hall, Miriam King, and Chad Ronnander. Integrated Public Use Microdata Series: Version 3.0 [Machine-readable database]. Minneapolis, MN: Minnesota Population Center [producer and distributor], 2004.

(3) "Firm Size" is the average firm size across all industries. Firm size data is from the 2000 County Business Patterns.

(4) See notes to Table 4 for further description of these variables. 


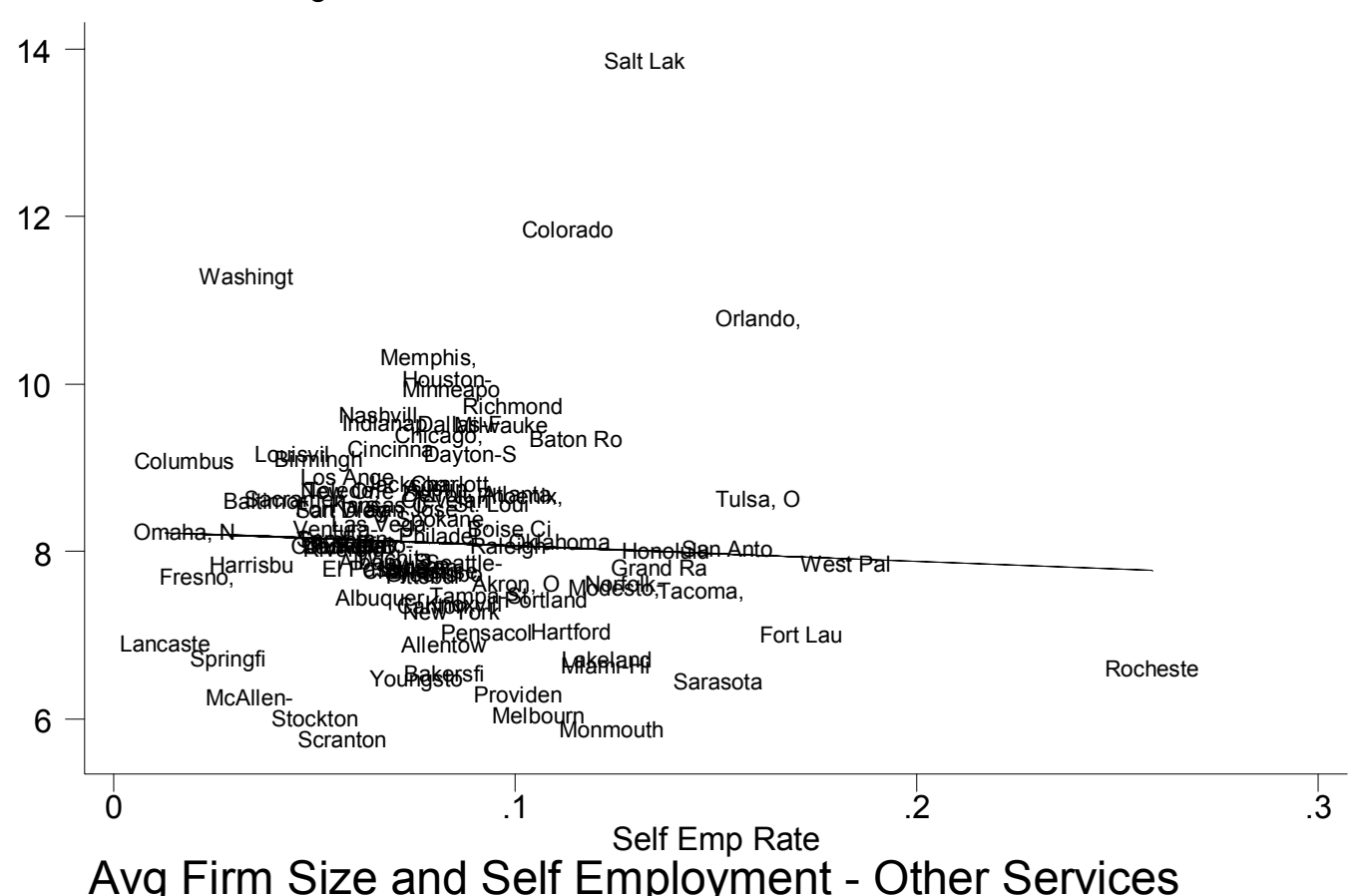

Figure 4

Notes:

(1) Share Self Employment Rate=(Self Employed Other Services)/(Total Employment Other Services)

(2) Self Employment data is from the 2000 Census microdata, from the Integrated Public Use Microdata Series (IPUMS) at http://usa.ipums.org/usa/. Steven Ruggles, Matthew Sobek, Trent Alexander, Catherine A. Fitch, Ronald Goeken, Patricia Kelly Hall, Miriam King, and Chad Ronnander. Integrated Public Use Microdata Series: Version 3.0 [Machine-readable database]. Minneapolis, MN: Minnesota Population Center [producer and distributor], 2004.

(3) "Firm Size" is the average firm size for Other Services. Firm size data is from the 2000 County Business Patterns.

(4) See notes to Table 4 for further description of these variables. 


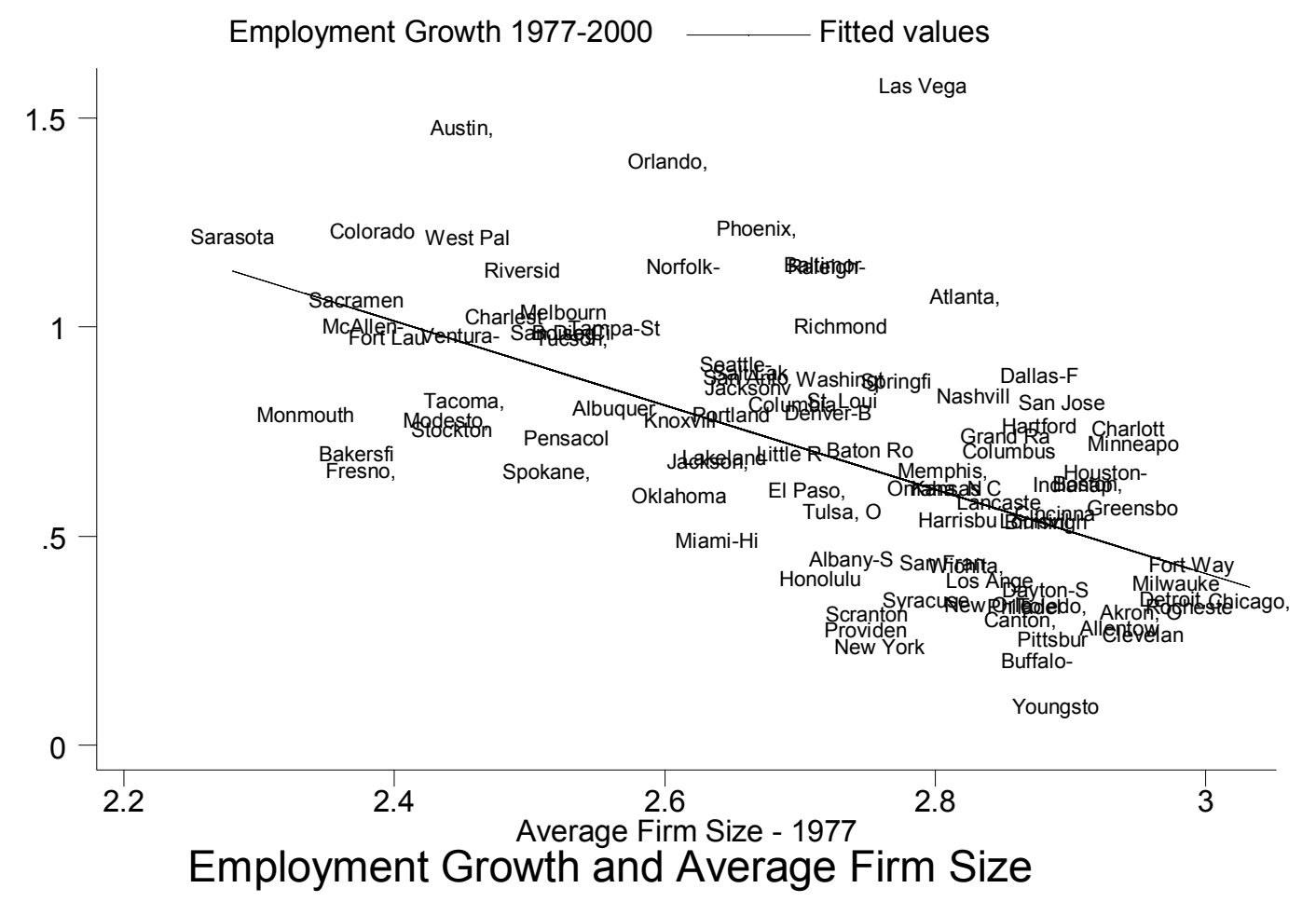

\section{Figure 5}

Notes:

(1) Data on Firm Size and Employment Growth from the 1977 and 2000 County Business Patterns

(2) County Business Patterns for 2000 from www.census.gov

(3) County Business Patterns for 1977 from United States Department of Commerce. Bureau of the Census, 1986-04-28, "County Business Patterns, 1977 [United States]: U.S. Summary, State, and County Data", hdl:1902.2/08464 http://id.thedata.org/hdl\%3A1902.2\%2F08464 Inter-university Consortium for Political and Social Research [distributor(DDI)]. 